\title{
Bir Alt-Alan ve Yöntem Olarak Karşılaştırmalı Siyaset
}

Makale / Article

Tuba Eldem*

\section{Öz}

Bu makalenin amacı siyaset biliminin metodolojik çekirdeğini oluşturan karşılaştırmalı siyasetin tematik, işlevsel ve yöntemsel boyutlarını mercek altına alarak Türkçe dilindeki karşılaştırmalı siyaset literatürünün gelişimine katkı sunmaktır. Nitekim önemli birkaç ders kitabı (Kalaycığlu ve Kağnıcıoğlu 2014; Sayarı ve Bilgin 2016; Yayla 2014) ve iki çeviri kitap (Newton ve Deth, 2014; Lane, 2014) dışında Türkçe literatür oldukça kısıtıdır. Bu makale bu konudaki eksikliğin giderilmesine katkı sunmak için karşılaştırmalı siyaseti, siyaset biliminin merkezi bir alt-disiplini olarak tanımlayarak diğer alt-alanlar ile ilişkisinin karşılaştırılması ile başlamaktadır. íkinci bölüm karşılaştırmalı siyasetin on dokuzuncu yüzyılın sonlarında Amerika Birleșik Devletleri'nde siyaset biliminin bir alt-alanı olarak ortaya çıkmasından bu yana tematik gelişimini tarihsel bir perspektifle gözden geçirmektedir. Üçüncü bölüm, 'neden karşılaştırmalııı' sorusuna eğilerek karşılaştırmalı siyasetin amaç ve işlevleri üzerinde durmakta, karşılaştırmalı siyasetin yöntem boyutuna odaklanan dördüncü bölüm, karşılaştırmalı siyasette kullanılan yöntemleri araştırılan vaka sayısına göre tek vaka $(\mathrm{N}=1)$, birkaç vaka (Küçük $\mathrm{N}$ ) ve birçok vaka (Büyük N) çalışmaları olmak üzere üçe ayırarak incelemektedir.

Anahtar Kelimeler: Siyaset Bilimi, Karşılaştırmalı Siyaset, Karşılaştırmalı Yöntem, Karşılaştırmalı Siyasi Kurumlar, Siyaset Bilimi Metodolojisi, Küçük-N Analizi, Vaka Analizi.

\section{Comparative Politics as a Subfield and a Methodology of Political Science}

\section{Abstract}

This article seeks to contribute to the development of the Turkish literature on comparative politics by examining its substantive, functional and methodological dimensions. Comparative politics is the central subfield that forms the methodological core of political science, yet apart from a few important textbooks (Kalaycığlu ve Kağnıcıoğlu 2014; Sayarı ve Bilgin 2016; Yayla 2014) and two translated books (Newton ve Deth, 2014; Lane, 2014), the Turkish literature on comparative politics is limited. This article seeks to fill this gap by first defining and examining the relationship of comparative politics with other sub-fields. The second section overviews the historical and substantive development of the comparative politics since its development as a distinct field of political science in the United States in the late nineteenth century till today. The third section turns the question of "why we compare" and discusses main objectives and functions of comparative politics. This section argues that comparative politics is a scientific sub-discipline that aims to reach generalizations and to identify and explain the differences and similarities between political institutions, actors and processes within the framework of a method composed of determined rules and standards. The fourth section focuses on the methodological aspects of comparative politics and examines the methods used in comparative politics by differentiating between Large-N, Small-N and single case $(\mathrm{N}=1)$ studies.

Keywords: Political Science, Comparative Politics, Comparative Method, Comparative Political Institutions, Political Methodology, Small-N Analysis, Case Study.

*Dr. Öğr. Üyesi | Fenerbahçe Üni., Siyaset Bilimi ve Uluslararası İlişkiler Böl. | tuba.eldem@fbu.edu.tr ORCID: 0000-0001-6264-255X | DOI: 10.36484/liberal.818214

Liberal Düşünce Dergisi, Yıl: 25, Sayı: 100, Güz 2020, ss. 37-68.

Gönderim Tarihi: 29 Ekim 2020 | Kabul Tarihi: 23 Aralık 2020 


\section{Siyaset Biliminin Bir Alt-Disiplini Olarak Karşılaştırmalı Siyaset}

Ünlü Amerikalı Siyaset Bilimci Harold Laswell'in (1936) ifade ettiği gibi siyaset, "kimin, neyi, ne zaman ve nasıl alacağının” mücadelesidir. Bu mücadele, bir cinsin diğeri üzerinde kurduğu ve özel alanda yeniden üretilen ataerkil tahakküm ilişkisinden, toplumsal sınıflar arasındaki üretim araçlarının kontrolüne, rakip çıkar gruplarının küçük bir belediye bütçesinden pay almak için girdikleri rekabetten, uluslararası süper güçler arasındaki askeri rekabete kadar geniş bir alanı kapsar. Siyaset bilimciler, siyaset dünyasının nasıl işlediğine ilişkin genel ilkeleri veya teorileri geliştirmek amacıyla iktidarın dağıllmı, uygulanması ve sonuçlarını incelerler. Giddens'ın (1987:7) “dönüştürücü kapasite” olarak tanımladığı iktidar veya güç kavramı “aktörlerin diğerleri için sosyal, politik ve ekonomik olarak mümkün olan parametrelerini yeniden tanımlama”, yani “içinde bulundukları bağlamı şekillendirme kapasitesi” olarak tanımlanabilir (Hay, 1997: 50). Bu kaynak ve değerlerin üretimi ve dağıtımında söz sahibi olmak için girişilen iktidar mücadelelerini çeşitli seviyelerde ve farklı boyutları ile analiz etmeye ve açıklamaya çalışan siyaset biliminin temel olarak dört, genişletilmiş olarak sekiz farklı alt-alanı vardır.

Siyaset bilimi disiplini geleneksel ve yaygın olarak "siyaset felsefesi ve teorisi”, "ulusal siyaset”, "karşılaştırmalı siyaset” ve "uluslararası ilişkiler” gibi dört temel alt-dala ayrılmaktadır (Kaufman-Osborn, 2006: 44-45). Amerika Birleşik Devletleri'ndeki başlıca siyaset bilimi araştırmaları alanları üzerine yapılan Amerikan Siyaset Bilimi Derneği (APSA) çalışması, araştırmacıların yoğunlukla bu dört alana yönelik çalışmalar yürüttüğünü ortaya koymaktadır. APSA’nın verilerine göre araştırmacıların yüzde 38'i Amerikan siyaseti (ulusal siyaset), yüzde 37'si karşılaştırmalı siyaset, yüzde 30'u uluslararası ilişkiler, yüzde 17'si ise siyaset felsefesi ve teorisi alanında çalışmaktadır (Trent, 2011: 193). ${ }^{1}$

Bu geleneksel dört alt-alanın yanına yakın zamanlı birçok sınıflandırma yeni alt-alanlar eklemiştir. Örneğin, Robert Goodin and Hans-Dieter Klingemann'in editörlüğünü üstlendiği "Siyaset Biliminde Yeni Bir El Kitabı” (1996) adlı kitapta disiplin; "siyasi kurumlar”, "siyasal davranış”, "karşılaştırmalı siyaset”, "uluslararası ilişkiler”, "siyaset teorisi”, "kamu politikası ve yönetimi," “politik ekonomi” ve "politik metodoloji” olmak üzere sekiz bölüme ayrılmıştır. Klingemann, Avrupa'daki siyaset biliminin müfredatının ise "siyaset teorisi ve siyasal düşünceler tarihi”, "ülkenin ve bölgenin siyasi sistemi”, "kamu yönetimi ve politika analizi”, "politik ekonomi ve politik

1 Araştırmacıların yüzde 10'unun kamu yönetimi ve bir diğer yüzde 10'unun ise metodoloji alanında çalıştığı görülmektedir. 
sosyoloji”, "karşılaştırmalı siyaset”, “uluslararası ilişkiler” ve "metodoloji” olmak üzere yedi temel bileşenden oluştuğunu tahlil etmektedir (2008: 374). Siyaset Bilimi disiplininde bu alt-alan kargaşası izlenimi, APSA Üyeleri Dizinine göz attığımızda daha belirgin hale gelmektedir. Dizinde üyeler, şu sekiz alanda sınıflandırmaktadır. 1-Amerikan hükümeti (ulusal siyaset), 2-karşılaştırmalı siyaset, 3-uluslararası politika, 4-yöntem, 5-siyaset felsefesi ve teorisi, 6-kamu yönetimi, 7-kamu hukuku ve mahkemeleri ve 8-kamu politikası. APSA'nın bu son sınıflandırması üzerinden ilerlersek, siyaset bilimini tematik ve fonksiyonel olarak sinıflandırabileceğimiz temel sekiz alt alanı vardır. Bunlardan altısı makro, ulusal ve mikro olmak üzere üç düzeyde tasvir edilebilecek tematik ve ikisi (siyaset teorisi ve metodoloji) disipline hizmet eden fonksiyonel alanlardır (Sly, 2018: 271).

Şema 1: Siyaset Biliminin İşlevsel ve Tematik Alt Disiplinleri

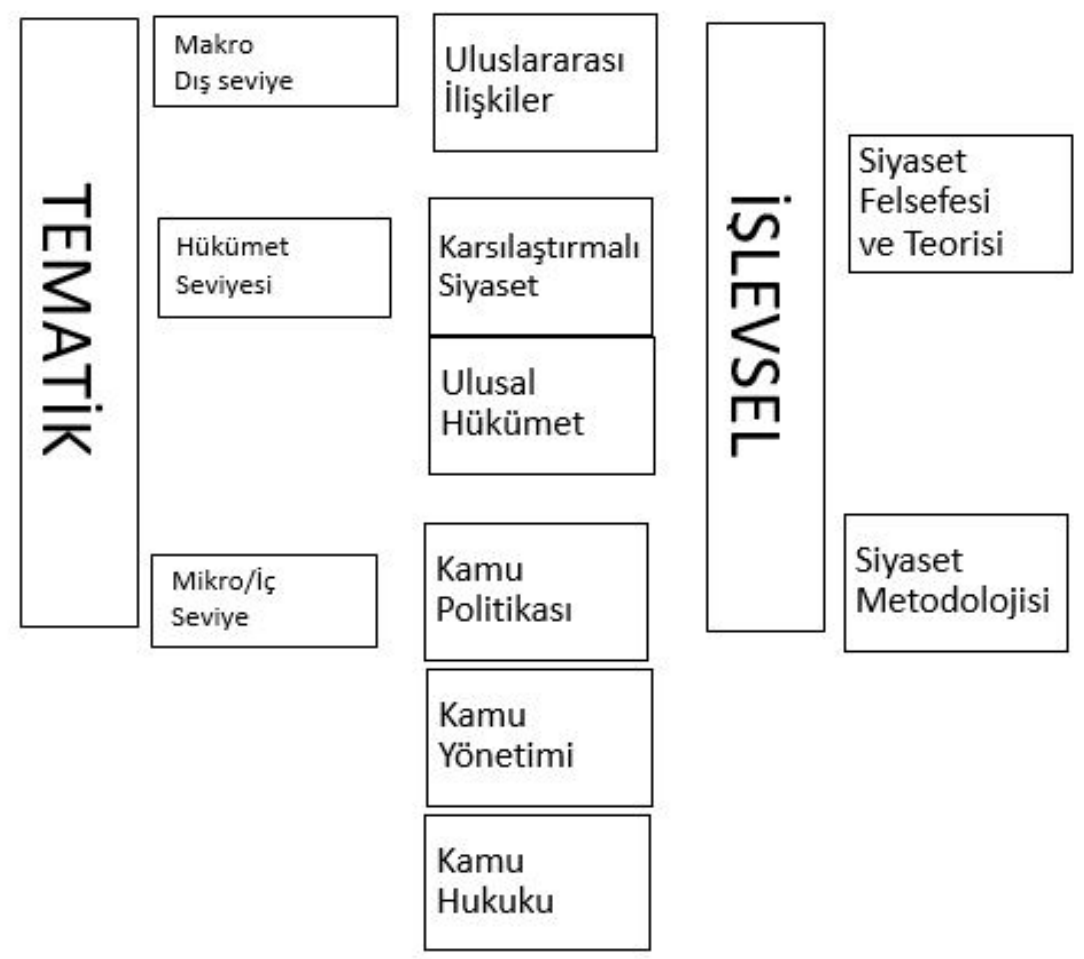

Fonksiyonel olarak siyaset biliminin gelişmesine hizmet eden siyaset felsefesi ve teorisi, Platon'dan başlayıp Rawls'a kadar uzanan siyasal düşünce tarihinin yanı sıra çağdaş siyasal yaşamdaki adalet, meşruiyet, demokrasi, özgürlük, eşitlik gibi felsefi bir boyuta sahip çeşitli değerlere yönelik normatif teoriyi kapsar. Siyasette olanı değil olması gereken olgu, norm ve kuralları 
ahlak felsefesi ile yakın ilişki içinde normatif (buyurucu) olarak yorumlayan siyaset felsefesi, devletlerin içişleri ve iç dinamiklerini kanıtlanabilir ampirik olgular üzerinden sistematik ve objektif (değer-bağımsız) analizine dayanan karşılaştırmalı siyaset alanından ayrılmaktadır. Karşılaştırmalı siyasetçiler, siyaset felsefesi ve teorisinden beslenseler de karşılaştırmalı siyaset literatürü çoğunlukla ampirik teoriye odaklanır.

Siyaset bilimcilerinin soru sorma ve araştırma yöntemlerini ele alan siyaset metodolojisi, siyaset biliminin bir disiplin olarak gelişmesine hizmet eden ikinci fonksiyonel alt-disiplindir. Olgular (ampirik kanıtlar) ile değerleri (normatif ve ahlaki inançları) birbirinden ayıran pozitivist teoriye rehberlik eden siyaset metodolojisinden karşılaştırmalı siyasetçiler ve siyaset biliminin uluslararası ilişkiler gibi diğer tematik alt-disiplinleri faydalanmaktadır. Siyaset metodolojisi, siyasi analiz için kullanılan istatistik, matematik ve biçimsel teoriyi içeren nicel yöntemlerin ve görüşme, gözlem ve odak grup yönetmeleri, arşiv araştırması, etnografi, vaka-analizi, karşı olgusal analiz, içerik analizi, söylem analizi ve karşılaştırmalı yöntem gibi çeşitli nitel yöntemlerin geliştirilmesi için çalışır.

Hem bir çalışma yöntemi hem de bir çalışma konusu içeren karşılaştırmalı siyaset (Wilson, 1996: 4; Laitin, 2002: 631), yöntem olarak kökeni Aristo'nun çalışmalarına dayanan karşılaştırmayı kullanarak siyasetin bilimsel olarak çalışılmasının metodolojik çekirdeğini oluşturur (Almond, 1966; Lasswell 1968; Powell vd., 2014; Hague vd., 2016). Bir başka deyişle, karşılaştırmalı siyaset, siyaset bilimi disiplininin merkezi alt-alanıdır çünkü siyaset bilimi kendisini bir disiplin olarak kurmak için en azından farklı türdeki politik sistemleri belirlemek ve karşılaştırmak zorundadır (Sly, 2018: 272). Çalışma konusu olarak karşılaştırmalı siyaset; bir devlet, toplum, ülke veya siyasi sistem içinde yer alan siyasi fenomen ve olayları anlamaya ve açılamaya odaklanmaktadır. Ülkeler arasındaki farkları ve benzerlikleri ve siyasal sistemler arasındaki örüntüleri, süreçleri ve düzenlilikleri araştırmakla ilgilenen karşılaştırmalı siyaset (Wiarda, 2000: 7), devlet oluşum süreçleri, rejim türlerinin sınıflandırılması, siyasi kurumların yapısı, siyasi aktörlerin rolü ve yönetişim performans süreçleri gibi konularla ilgilenmektedir.

Bir ulusun iç sistemindeki siyasi davranışları ve kurumları inceleyen ulusal siyaset, farklı coğrafi bölgeler içindeki ve arasındaki siyasal vakaları analiz eden ve karşılaştıran karşılaştırmalı siyasetin bir alt alanı olarak düşünülebilir (Sly, 2018: 272). Ulusal düzeyde çoğu sistemde, kaynakları yöneten ve güç kullanan bir yürütme kurumu, kaynak ve gözetimi tahkim eden yasama kurumu ve anlaşmazlıkları ele almakla görevli yargı kurumları vardır. Kamu 
yönetim, hükümet politikalarının uygulanması yollarını; Kamu politikası, hükümetlerin sağlık, çevre, ekonomi, yiyecek, giyecek ve barınma gibi birçok farklı alanda kamu kararlarını alma süreçlerini, kamu hukuku ise siyasi süreçte hukukun ve mahkemelerin rolünü inceler.

Daha küresel düzeyde farklı siyasi sistemlerin birbirleriyle etkileşime girmesini inceleyen uluslararası İlişkiler alt-alanı, ulus-devletler arasındaki ilişkileri ve Birleşmiş Milletler, Dünya Bankası ve NATO gibi uluslararası kuruluşların faaliyetleri ile uluslararası teröristler, sivil toplum kuruluşları ve çok-uluslu şirketler gibi devlet-dışı uluslararası aktörlerin etkileşimini araştırır. Devletlerin dış politikaları ve ilişkileri ile ilgilenen uluslararası ilişkiler, devletlerin içişleri ve iç dinamikleri ile ilgilenen karşılaştırmalı siyasetten çalışma alanı açısından farklılaşmaktadır. Bu farklılık, uluslararası ilişkiler ve karşılaştırmalı siyaset alt-disiplinlerinin temel kitaplarının başlıklarında net bir şekilde göze çarpmaktadır. Örneğin, Hans Morgenthau (1948) ünlü uluslararası ilişkiler ders kitabının adı Uluslar Arası Siyaset (Politics Among Nation) iken, Joseph La Palombara'nin (1974) karşılaştırmalı siyaset alanındaki temel ders kitaplarından biri kabul eden kitabının başlığı Uluslar İçinde Siyaset'tir (Politics Within Nations). Uluslararası ilişkilerin genel olarak "dışarıdan gelen" karşılaştırmalı siyasetin ise genellikle "içeriden gelen” bir yaklaşıma dayandığını söylenebilirse de küreselleşme süreci ile uluslararasında artan karşılıklı bağımlılık ve bağlanmışlık, ulus-içi ve ulus-dışı değişkenler arasındaki ilişkiyi çift taraflı olarak attırmış ve alt-alanlar arasındaki ayrımı gittikçe daraltmıştır (Bates, 1997).

\section{Çalışma Konusu olarak Karşılaştırmalı Siyaset}

İkinci Dünya Savaşıından sonra Amerika Birleşik Devletleri'nde (ABD) geliştirilen karşılaştırmalı siyaset alt alanı, ana tema olarak modern kapitalist dünyanın kökenlerini açıklama ve geleceği yansıtma sorununu ele almıştır (Hanson ve Kopstein, 2015: 72). Bu bağlamda alt alan, on dokuzuncu ve yirminci yüzyılın en etkili üç büyük teorisyenlerinden olan Karl Marx, Max Weber ve Emile Durkheim ve özellikle sosyolog Talcott Parsonsıın çalışmalarında sunulan bu teorilerin büyük sentezi tarafından şekillendirilmiştir (Hanson ve Kopstein, 2015; Munck, 2007). Karşılaştırmalı siyasetçilerin üzerinde durduğu konular toplumların yaşadığı sorunlar doğrultusunda kuşaktan kuşağa değişse de liberal demokratik kapitalist düzenin ve ona karşı gelişen anti-liberal dinamiklerin anlaşılması ana tema olarak varlığını sürdürmüştür. Yirminci yüzyılın ilk yarısında yaşanan Büyük Buhran ve Avrupa'da faşizmin yükselişi, karşılaştırmalı siyaset bilimcileri hükümetlerin istikrarlı bir 
ekonomik büyümeyi teşvik etmek ve vatandaşlarını istikrarsızlaşan pazarın yıkıcı sonuçlarından korumak için hangi politikaları uygulayabileceklerini araştırmaya iterken (Schumpeter,1942); Almanya'nın Weimar Cumhuriyeti döneminde Nazi Partisi'nin iktidara gelmesi, demokrasi-karşıtı siyasi aşırılık yanlılarının iktidara gelme olasılığını azaltılacaksak şekilde seçim sistemin nasıl tasarlanabileceğini araştırmaya sevk etmiştir (Clark vd., 2018: 30).

1930 ve 1940'larda Avrupa'dan ABD’ye yönelik yaşanan beyin göçü ve 1950'lerde Amerikan sosyal bilimlerde ortaya çıkan davranışsal devrim, karş1laştırmalı siyasetin bir alt-disiplin olarak gelişmesinde önemli rol oynamıştır (Munck, 2007; Wiarda, 2000). Her ne kadar karşılaştırmalı siyasetin kökenleri, on dokuzuncu yüzyılın sonlarında ABD'nin önde gelen üniversitelerinde siyaset bilimi bölümlerinin kurulmasına ve yirminci yüzyılın başında karşılaştırmalı devlet derslerinin ABD'nin önde gelen üniversitelerinin siyaset bilimi müfredatlarına eklenmesine dayansa da yirminci yüzyılın ortalara kadar formel geleneğin egemenliği altında olan alt-alan; yürütme, yasama, yargı ve bürokrasi gibi çeşitli kurumların yetkileri, merkezi ve yerel yönetimler gibi yönetsel örgütün çeşitli kolların ve anayasa ve diğer resmi yapıların nasıl işlediği gibi konuları İngiltere, Fransa, Almanya ve Sovyetler Birliği gibi kısıtlı birkaç ülke için incelemiştir (Munck, 2007: 32-41; Wiarda, 2000: 18). 1950'lerin sonlarında ve 1960'ların başında, yeni veya gelişmekte olan birçok ‘Üçüncü Dünya' ülkesinin dünya sahnesine girmesi ile karşılaştırmalı siyaset coğrafi ve kavramsal bir genişleme yaşamış ve 1960’lardan itibaren karşılaştırmalı siyasetçiler; Afrika, Asya, Latin Amerika ve Orta Doğu'nun gelişmekte olan ülkelerinde görülen patronaj ağları, devlet kayırmacılığ1 ve kronizm, askeri müdahaleler, darbeler ve devrimler gibi siyasetin gayri-resmi boyutlarını incelemeye başlamışlardır (Wiarda, 2000: 9).

1950'ler ve 1960'larda Amerikan sosyal bilimlerine doğa bilimlerindeki gibi genel geçer herkesçe kabul edilen teoriler oluşturmayı ana amaç olarak benimseyen davranışsalcılık akımının egemen olması, karşılaştırmalı siyasetin içeriğini kamuoyu, siyasi davranış, çıkar grubu, lobicilik, karar verme, siyasi kültür ve siyasi sosyalleşme gibi siyasetin daha gayri resmi ve dinamik yönlerini de içerecek şekilde genişletmiştir (Almond ve Verba 1963). Davranışsal devrim, anket çalışmalarının bireysel veri toplamak için sistematik bir araç olarak kullanılmasına yol açmış, 1960'lerde sosyal bilimlerde kullanılmaya başlayan bilgisayar teknolojisi, binlerce bireye ait geniş veri setlerini barındıran anketlerin analiz edilmesini kolaylaştırmış ve siyasi fenomenler arasındaki ilişkinin gücünün sayısallaştırılarak test edilmesine imkan veren çoklu regresyon ve faktör analizi gibi istatiksel tekniklerin 
geliştirilmesine ve yaygın şekilde kullanılmasına yol açmıştır (Caramani, 2017: 11-12; Munck, 2007:41-47).

1960'larda modernitenin yükselişi ve yayılması, gittikçe daha fazla maddi refah ve bireysel özgürlüğe yol açacak ilerici bir gelişme olarak gören modernleşme teorisi karşılaştırmalı siyasette egemen hale gelmiştir (Lipset 1959; Rostow, 1960). Toplumların modern ekonomik kalkınma aşamasına ulaşması için kültürel, toplumsal ve siyasal bir değişim sürecine gereksinim duyduğunu varsayan ekonomik modernleşme teorisinden etkilenen karşılaştırmalı siyasetçiler, İkinci Dünya Savaşı'nın ardından ortaya çıkan sömürgecilik ve Amerika Birleşik Devletleri'nin soğuk savaş sırasında izlediği dış politikanın da etkiyle siyasi kalkınma sorununa odaklanmış ve Batı dışı toplumlarda geri kalmışlığının anlaşılması, açıklanması ve bu toplumların gelişmesine katkı sağlanması amacıyla birçok araştırma yapmışlardır (Nye, 1967; Huntington, 1965; 1968; Kesselman, 1973; Ward ve Rustow, 1964; Walton, 1972). 1970 ve 1980'lerde ise "gelişmekte olan dünyada" devam eden yoksulluk ve siyasal huzursuzluk ve 1970’lerde Orta Doğu petrol krizinin Batı kapitalizminin gelecekteki istikrarı hakkında artan şüphelerle birleştiğinde, modernleşme paradigmasının teleolojik ve işlevselci öğelerinin bir dizi eleştirisine yol açarak küresel kapitalizm ve demokrasinin yayılması hakkında Marksist ve eleştirel teorik perspektiflerin yeniden canlanmasını teşvik etmiştir (O’Donnell, 1973; Tilly, 1984; Evans, 1979; Evans vd., 1985; Wallerstein 1974). Batı Avrupa'da refah devleti ve sosyal politikaların genişlemesi karşılığında işçi sınıfının kapitalist ekonomiyi ve serbest ticareti kabul etmesiyle ortaya çıkan 'savaş sonrası anlaşma'ya veya 'sınıf uzlaşına' dayanan kapitalist ekonomilerin uluslararası ekonomik krizlere karşı dayanıklılığı ve farklı kapitalizm türlerinin krizlerde izlediği farklı sosyo-ekonomik politikalar, 1980'lerden itibaren karşılaştırmalı siyaset ve karşılaştırmalı politik ekonominin önemli birer konusu haline gelmiştir (Zysman, 1983; Katzenstein, 1985; Hall 1986; Esping-Andersen, 1990; Berger ve Dore, 1996; Boyer ve Drache, 1996; Coates 2000; Hall ve Soskice 2001). Yüzyılın son on yılında, Soğuk Savaşın sona ermesi ve aniden Doğu ve Orta Avrupa'daki düzinelerce ülkenin planlı merkezi ekonomilerden piyasa odaklı ekonomik sisteme ve tek parti diktatörlüklerinden demokratik rejimlere geçmesi karşılaştırmalı siyasetçilerin bu ikiz geçiş süreçlerini mercek altına almalarına yol açmıştır (Diamond 1999; Linz ve Stepan, 1996; Kopstein ve Reilly, 2000; Way ve Levitsky, 2007). Yirmi birinci yüzyılın içinde bulunduğumuz ilk yirmi yılında ise hâlâ liberal kapitalist demokratik düzen ve ona meydan okuyan anti-liberal rejim dinamiklerinin anlaşılması karşılaştırmalı siyasetçilerin üzerinde durduğu ana temalar arasındadır. Bu bağlamda, konsolide olan kurumsallaşmış demokrasilerin de dahil olduğu birçok ülkede son yirmi 
yılda yaşanan demokratik kriz, dünyanın birçok bölgesinde yükselen popülizm, illiberal demokrasi ve rekabetçi otoriterlik karşılaştırmalı siyasetin günümüzde üzerinde durduğu ana konuları oluşturmaktadır. Diğer yandan, eski Sovyet ülkelerinde ve Balkanlar'da 2000'li yılların başında gerçekleşen renkli devrimler ve Arap Baharı diye adlandırılan 2011 yılında Ortadoğu'yu etkisi altına alan halk ayaklanmaları karşılaştırmalı siyasetçileri rejim değişiklikleri konusuna yöneltirken, 2014'de Irak ve Suriye'deki İslam Devleti'nin (ISIL) halifelik ilan etmesi ve Suriye İç Savaşı'nın yarattığı istikrarsızlıkla beraber ortaya çıkan mülteci krizi, karşılaştırmalı siyasetçileri, devlet otoritesi ve kapasitesi, iç savaş ve göç gibi konuları daha derinden incelemeye sevk etmiştir.

\section{Neden Karşılaştırırız? Karşılaştırmalı Siyasetin Amaç ve İşlevleri}

Karşılaştırmalı siyasetin temel amacı siyasal sistemler, aktörler ve süreçler arasındaki benzerlik ve farklıları ampirik olarak tanımlamak, açıklamak ve tahmin etmektir (Caramani, 2017:4). Karşılaştırmalı siyasetin ilk amacı, siyasal dünyadaki benzerlik ve farklıları tanımlamak ve bu tanımlamaları kullanarak kavramlar, sınıflandırmalar ve tipolojiler gibi bir dizi analitik araçlar üretmektir. Karşılaştırmalı siyasetteki sınıflandırmanın ve tipolojiler geliştirmenin kökeni Platon ve Aristoteles gibi Antik Yunan filozoflarının siyasal düzenleri türlerine göre ampirik gözlemlerle sınıflandırma çabasına dayanmaktadır. Günümüzde karşılaştırmalı siyasette devletlerin sınıflandırması; demokratik ve otoriter ülkeler, gelişmiş ve az gelişmiş ülkeler, merkez ve çevre ülkeler gibi belirli ülkelerin hangi gruba dahil olduğunu belirlemeye yardımcı olan teorik olarak türetilmiş bir dizi kritere dayalı ikili sınıflandırma veya daha büyük farklılaşma imkânı tanıyan daha karmaşık bir rejim ve hükümet sistemleri sınıflandırması şeklinde olmaktadır. Siyasal rejim ve hükümet sistemlerinin yanı sıra ulusal politik ekonomileri, refah devletlerini ve sosyal politikaları, seçim sistemlerini, parti-sistemlerini ve yürütme, yasama ve yargı gibi kurumları yapısal türlerine göre sınıflandıran birçok tipoloji bulunmaktadır. Bu tipolojiler, karşılaştırmalı siyasette "kavram inşa-etme, ölçümü keskinleştirme, boyutsallığı keşfetme, açıklayıcı iddiaları düzenleme ve kategorik değişkenler inşa etme" gibi önemli işlevleri yerine getirmektedir (Collier vd., 2008; 2012).

Karşılaştırmalı siyasetin ikinci amacı bu tanımlanan ve sınıflandırılan benzerlik ve farklıları açıklamaktır. Diğer tüm bilimsel disiplinler gibi karşılaştırmalı siyasetçiler de bu farklıları açıklamak için hipotezler geliştirir ve bu hipotezleri vakalar üzerinden elde ettikleri ampirik verilerle karşılaştırarak test ederler. Sistemlerin, aktörlerin ve süreçlerin karşılaştırılması, 
rasyonel seçim, kültürel ve yapısal teori gibi belirli teorilerden türetilen hipotezlerin, uluslararası benzerlikler ve farklılıklar incelenerek test edilmesine izin vererek adeta siyasal hayat hakkındaki argümanlarımızın sınanacağı bir laboratuvar işlevi görür. Karşılaştırmalı siyasetçiler, "yoksulluk-yolsuzluk" (Neudorfer, 2015), “demokrasi-ekonomik kalkınma” (Boix, 2011; Przeworski vd., 2000; Rueschemeyer vd., 1992) “sosyal devrimler ve göreceli yoksunluk" (Gurr, 1970) "siyasal kültür ve demokrasi” (Inglehart ve Welzel, 2003) gibi değişkenler arasında karmaşık ilişkileri birkaç veya birçok vakayı karşılaştırarak ortaya koymaya çalışırlar. Nitel veya nicel verililerin analizini mantıksal veya istatiksel teknikler kullanarak yapan karşılaştırmalı siyasetçiler, ana açıklayıcı değişken ve sonuç değişkenleri dikkatlice tanımlayarak aralarındaki ilişkileri ampirik kanıtları karşılaştırarak gösterirler. Sartori'nin kısa ve net şekilde ifade ettiği gibi karşılaştırarak araştırmacılar, bazı değişkenleri kontrol ederek hipotezlerini test etmiş olurlar (1991; 1994).

Karşılaştırmalı siyasetin nihai ve en zor hedefi, bu ilişkiler arasındaki nedensellik bağlarını açıklayan teorilere ve genelleştirmelere dayanarak gelecekteki siyasi sonuçlar hakkında tahminde bulunmaktır. İnsan ve sosyal örgütlenmelerde iki değişken arasında kesin, istisnasız bir şekilde tespit edilmiş, olasılığa bağlı olmayan ilişkilere çok sık rastlanmadığı için karşılaştırmalı siyasette tahmin olasılık savları üzerine kuruludur. Dolayısı ile karşılaştırmalı siyasette tahmin, bir ulusun seçim sistemini çoğunlukçu sistemden orantılı seçim sistemine değiştirmesinin o ülkedeki parti sayısını artırma eğiliminde olacağ1 (Duverger, 1959; 1972; Riker, 1982) veya yüksek siyasal kutuplaşma yaşanan ülkelerde başkanlık sistemlerinin parlamenter hükümet sistemine göre daha fazla kutuplaşmaya yol açma olasılığının daha yüksek olacağı gibi olasılıklı terimlerle yapılmaktadır (Linz, 1990; 1994; Stepan ve Skach 1993; Lijphart, 1995; Cheibub ve Limongi, 2002; Mainwaring ve Shugart, 1997).

\section{Karşılaştırmalı Yöntem}

Karşılaştırmalı analizin kural ve standartlarını belirleyen karşılaştırmalı yöntem, karşılaştırabilir açıklayıcı bilgi birikimini arttırmak, anahtar değişkenler arasındaki ilişkiyi ve nedensellik bağlarını ortaya koymak ve tahmin potansiyelini geliştirmek için karşılaştırmalı analizin nasıl yürütülmesi gerektiği üzerinde durur (Caramani 2017; Keman ve Pennings 2017). Karşılaştırmalı yöntem, geleneksel olarak istatistiksel ve deneysel yöntem gibi, dışsal değişkenlerin etkisini tanımlamaya ve ölçmeye çalışan fakat bunlardan farklı olarak birkaç vakanın sistematik seçimi yoluyla anahtar değişkenlerin kontrolünü sağlayan ve orta seviyede kavramsal soyutlama yolu ile bu vakaları analiz 
eden bir araştırma yöntemidir (Lijphart, 1971:685; Collier, 1991: 9-12; Collier, 1993; Landman, 2006: 29, 67-83). Karşılaştırmalı yöntem üzerine yapılan bu ilk çalışmalar, nicel analiz kullanarak birçok vakanın karşılaştırmasını, istatistiksel yöntemle, birkaç vakanın nitel analizini karşılaştırmalı yöntemle ve tek bir vakanın nitel analizini vaka analiz yöntemiyle özdeşleştirmiştir. Örneğin Lijphart (1971), karşılaştırmalı yöntemi en az iki tane gözlem içeren ve istatiksel analiz uygulamasına izin vermeyen az sayıda vakanın sistematik karşılaştırması olarak tanımlamaktadır. 2000’lardan beri literatürde görüş birliğine varılan yeni yaklaşım ise karşılaştırma yolu ile siyaset hakkında büyük çıkarımlar yapıyorsa ve incelenen vakanın dışında diğer vakalara da uygulanabilecek kavramlar kullanıyorsa vaka sayısına bakılmaksızın tüm bu çalışmaların karşılaştırmalı yöntem stratejileri olarak değerlendirilmesi yönündedir (Landman, 2008:27; Laitin, 2002: 631; Lichbach ve Zuckerman 1997: 4; George ve Bennett 2005; Wiarda 2000; Brady ve Collier, 2010;).

Sosyal bilimlerde vaka, tek bir noktada veya bir süre boyunca gözlemlenen mekansal olarak sınırlandırılmış bir fenomeni (birimi) ifade eder (Gerring, 2007:19). Karşılaştırmalı siyasetteki temel analiz birimi ulus-devletler olsa da aslında bir vakanın mutlaka bir ülke ile ilişkilendirilmesi gerekmez. İller, şehirler gibi alt ulusal birimler; yasama ve yürüme gibi kurumları kapsayan iç siyasal yapılar; seçmenler, partiler, sosyal hareketler ve çıkar gruplar gibi bireysel ve kolektif aktörler; ve sağlık, eğitim, sosyal refah gibi kamu politikaları yapımı, iletişim ve sosyalleşme süreçleri ve siyasal kültür gibi çeşitli siyasal süreçler sıklıkla bir vaka olarak incelenir. Karşılaştırmalı yöntem, bu vakaların çoklu özelliklerinin değişkenler arasındaki anlamlı bir ilişki temelinde gözlemlenmesi ve karşılaştırılmasına olanak tanır (Keman ve Pennings, 2017:51-52). Bir değişken, mekansal veya zaman içinde birçok durumda sistematik olarak gözlenen ve ölçülen kavramı ifade etmektedir. Bağımlı değişken araştırmanın açıklamaya çalıştığı siyasi sonuçları ifade ederken; bağımsız değişken bağımlı değişkeni açıklayan nedensel veya açıklayıcı değişkendir. Bağımlı ve bağımsız değişkenler arasında ampirik olarak belirli bir sayıda gözlemle gösterilen ilişkiler vakalar arasındaki benzerliklerin ve farklıların anlaşılmasını sağlar.

Kaç vakanın araştırmaya dahil edileceği, hangi vakaların seçiminin uygun olduğu ve bu vakaların hangi yöntemle (nitel, nicel veya tarihsel) kullanılarak en iyi analiz edilebileceğine göre karşılaştırmalı yöntem farklı biçimler almaktadır. Vakaların seçiminde anahtar soru, kaç tane olması gerektiğidir, bu bağlamda tek vaka, birkaç vaka ve birçok vaka olmak üzere üç ana seçenek vardır. Birçok vakanın niceliksel göstergelerinin istatiksel teknikler kullanarak karşılaştırması genellikle "büyük-N" karşılaştırması ve geleneksel olarak karşılaştırmalı yöntemle özdeşleştirilen birkaç gözleme sahip vakanın 
niteliksel özelliklerinin karşılaştırılması 'küçük-N' karşılaştırması olarak adlandırılır. Burada $\mathrm{N}$ karşılaştırılan vaka sayısını ifade etse de nicel verilerin istatiksel analizinin yapıldığı çalışmalarda, N'in toplam vaka sayısından ziyade toplam gözlem sayısını ifade ettiği görülür. Burada araştırmanın nihai çıkarımının açıklamaya çalıştığı birimleri ifade eden vaka ile vakada araştırılan değişkenin aldığı değer ya da puanı ifade eden gözlem birimi arasındaki ayrım önem arz etmektedir. İstatiksel çalışmalarda değişken sayısının gözlem birimi (değer) sayısı ile çarpımının sonucu $\mathrm{N}$ ile gösterilerek toplam incelenen gözlem sayısını ifade eder. Nitekim, birçok-ülkenin karşılaştırmalı analizinde, toplam gözlem sayısı ülke sayısının yıl sayısı ile çarpımını temsil ettiği uluslar-arası zaman serisi veri setleri kullanılmaktadır. Diğer yandan, zaman içindeki değişime odaklanan (zamanlar-arası) ya da vaka-içi kesitsel karşılaştırmaya odaklanan birçok gözleme sahip olan tek veya birkaç vakalı çalışmaların sayısı da gittikçe artmaktadır (Gerring 2006:19; King vd.,1994:52, 116-117; Bennett ve Elman 2006). Örneğin, Robert Putnam'in (1993) 'Demokrasi Çalıştırmak’ adlı eseri çıkarımlarını birçok-gözleme dayanarak Büyük-N'den yapan önemli tek vaka çalışmaları arasındadır. Bu bağlamda bu çalışma, gözlem sayısına bakmaksızın çalışmanın çıkarımlarının yapılacağı analiz biriminin sayısı açısından karşılaştırmalı yöntemleri tek bir vaka $(\mathrm{N}=1)$ birkaç vaka (Küçük-N) veya birçok vakaya (Büyük $\mathrm{N}$ ) odaklanan araştırma tasarımları olmak üzere üçe ayırarak incelemektedir.

\section{Büyük-N Çalışmaları ve Birçok Vaka Analizi}

Birçok vaka analizleri, birkaç anahtar değişkenin etkisinin mümkün olduğunca çok sayıda vakada test edildiği, böylece geniş çapta genelleştirilebilen evrensel yasaların tanımlandığı açıklayıcı çalışmalardır. Birçok vakanın karşılaştırılması, doğa biliminde bulunan deneysel yönteme en yakın yöntemdir. Birçok-vaka analizlerinde, araştırmacılar teorik olarak doğrulanmış örnekleri değil, daha büyük boyutlu örnekleri kullanmaktadır. Bu nedenle, birçok vaka analizleri, incelenmekte olan vakanın benzersiz karakteri ile daha az, değişkenler arasındaki soyut ilişkilerle daha fazla ilgilenmektedir. Bağlamsal analiz birimleri olan vakalar (ülkeler, sistemler, rejimler, kültürler, vb.) teorik olarak ilgili özelliklere sahip vakalar olarak kabul edilerek, iki veya daha fazla değişkenin ne kadar değişebileceği belirlenmektedir. Her ne kadar Huntington'un (1996) Medeniyetler Çatışması gibi birçok vakayı nitel yöntemlerle analizinin örnekleri olsa da birçok vakayı aynı anda karşılaştıran çalışmaların çoğunda nicel yöntemler kullanılmaktadır. İlişkisel yöntemler olarak da anılan nicel yöntemde, sadece değişkenler arasında belli eğilimler ya da aynı anda oluşan değer değişiklikleri tahlil edebilir. 
1950 ve 1960’larda sosyal bilimlerde davranışçı devrimin ortaya çıkmasıyla siyasal gelişme, modernleşme ve siyasal istikrar gibi büyük sorunlar üzerinde çalışan siyaset bilimcileri tarafından kullanılmaya başlanan bu yöntem veri setlerine daha fazla sayıda vaka dahil edilerek ve vaka-içi ve vakalar-arası eşzamanlı ve tarihsel analiz boyutları da dikkate alınarak gittikçe daha karmaşık hale gelmiştir. Günümüzde bu tür çalışmalarda yirmi ila elli yıl arasında değişen ve 150 ila 194 ülkeyi kapsayan veri setleri sıklıkla kullanılmaktadır. Örneğin, Woodrow Wilson Vakfı'nın siyaset bilimi alanında Amerika Birleşik Devletleri'nde 2000 yılında basılan en iyi kitap ödülünü alan Demokrasi ve Kalkınma: Dünyadaki Siyasi Kurumlar ve Refah (Przeworski vd., 2000) adlı çalışma, 1950'den 1990’a kadar 135 ülkeyi ve 1645 yıllık demokrasi, 2482 ylllık diktatörlük, 39 demokrasiden diktatörlüğü geçiş ve 49 diktatörlükten demokrasiye geçişi kapsayan geniş veri setini kullanarak siyasi rejimler ve maddi refah arasındaki ilişkiyi incelemiştir. Bu konudaki önceki nicel çalışmalardan metodolojik olarak farklılaşan çalışmada, seçim yanlılığı sorunundan kaçınmak için karşı olgusal metodoloji ${ }^{2}$ benimsenmiş ve Nobel ödüllü James Heckman tarafından geliştirilen iki aşamalı regresyon modeli kullanılarak zengin ülkelerdeki istikrarlı demokrasinin, kalkınma ve demokrasi arasında genel istatistik ilişkisini yönlendirebilecek rakip bir nedensel mekanizma olarak ortaya koyulmuştur. Zamansal ve mekânsal olarak geniş bir örnekleme sahip olan bu tür birçok vaka çalışmaları seçim yanlılığı riskini kontrol ederek güçlü çıkarımlar yapılmasını sağlar ve bu yolla teori inşasına katkıda bulunur. Rakip açıklamaları ve bağımsız değişkenleri kontrol eden ve uygulaması diğer araştırmacılar tarafından kontrol edilebilen standart teknikler kullanarak büyük miktarlarda verilerin kesin ilişkisel analizini sunabilmelerinin yanı sıra geniş kapsamından olayı daha fazla vaka için güçlü çıkarımlar ve genellemeler yapma yeteneği ve test edilen teoriden beklenen sonuçları doğurmayan 'sapkın' ülkeleri veya 'aykırı değerleri' tanımlama yeteneği bu yöntemin diğer avantajları arasındadır (Hague vd., 2016: 447-455; Landman, 2008: 27; 51-65).

Tüm bu avantajlarına rağmen değişken-odaklı çok-vakalı istatiksel analizler, gerekli ve yeterli nedenler, karmaşık nedensel mekanizmalar, tarihsel süreçler ve farklı vakaların bağlamsal özelliklerine ve değişkenlerin çoklu etkileşimine büyük ölçüde bağımlı olan daha derin anlam ve anlayışları içeren birçok konuyu analiz etmek için uygunsuz bulunur (Ragin, 1987; Mahoney ve Rueschemeyer, 2003; Mahoney, 2004; 2007; Landman, 2008). Her iki

2 Karşı-olgusal metodoloji aynı koşullar altında eğer başka kurumlar olsaydı sonuçlar ne olurdu sorusunu soran ve rastgele olmayan vaka seçiminden kaçınılmasına yardımcı olan bir düşünce deneyi gibi düşünülebilir. 
değişkenin de üçüncü, ölçülmemiş bir faktöre bağlı olmasından dolayı ortaya çıkan sahte korelasyon riski, değişkenlerin arasındaki nedensellik yönünün belirlenmesinde yaşanan zorluk, birçok vaka ve çoğu zaman periyodu için verilerin sınırlı kullanılabilirliği, yapısı ve özellikleri açısından standart istatistiksel analiz yöntemlerinin varsayımlarının çoğunu ihlal eden kabaca ve geniş ölçülen ve çoğu zaman esneyerek soyutlaşan kavramlar ve giderek karmaşıklaşan veri setlerini analiz etmek için gerekli olan matematiksel ve hesaplama becerileri bu yöntemin diğer dezavantajları arasındadır (Landman, 2008:27; Hague vd., 2016: 455-56).

\section{Küçük-N Çalışmaları ve Birkaç Vaka Analizi}

Geleneksel olarak karşılaştırmalı yöntemle özdeşleştirilen (Lijphart, 1971; Collier 1991;1993) ve "karşılaştırılabilir vakalar stratejisi" (Lijphart, 1975), “odaklanmış karşılaştırma” (Hague vd., 2016) veya 'vaka odaklı' (Ragin 1994) Küçük-N çalışmaları olarak da adlandırılan birkaç vaka analizi genellikle, karşılaştırma için iki ila bir düzine veya daha fazla vakanın kasıtlı ve sistematik olarak seçilerek derinlemesine karşılaştırılmasını içerir (Landman, 2008: 27; Hague vd., 2016). Bu yöntemin tanımlayıcı özelliği, olası vakalar evreninden birkaç vakanın sistematik ve kasıtlı seçimi ile anahtar değişkenlerin kontrolünü sağlamasıdır. Birkaç vaka analizinde, istatistiksel yönteme rehberlik eden aynı mantık temelinde değişkenler arasında varsayımsal nedensel ilişkiler test edilir fakat bu "vakaların bağımsız değişkenlerin varyansını maksimize ve kontrol değişkenlerin varyansını minimize edilecek şekilde seçilmesi yolu ile olur" (Lijphart, 1975: 164). Nitel analize yönelmesi ve bağlama değer verme gibi iki ana eğilimi bünyesinde barındıran Küçük-N analizi (Ragin, 1987:23), birkaç vakaya özgü nüansları daha fazla içerdiği için çok-vakalı analizden detay açısından daha yoğun, fakat genelleştirme açısından daha az kapsamlıdır. Kavramsal esnemenin daha az görüldüğü bu küçük-N çalışmaları, seçilen vakaların içinde bulundukları bağlamın dikkatli karşılaştırması ile çoklu açıklayıcı faktörün yapılandırılmasını ortaya çıkarır ve tarihsel dizilerin ve savaşlar, devrimler ve ekonomik krizler gibi belirli tarihsel olgu ve olayların açıklanmak istenen sonuçtaki etkisinin daha iyi tahlil edilmesine olanak sağlar.

Birkaç vaka analizinde, karşımıza çıkan en önemli kısıt "çok değişken, küçük N" diye adlandırılan gözlemlenen vaka sayısından daha fazla değişkene sahip olunması sorunudur (Lijphart, 1975:171). Birkaç vaka analizinde bu sorunu minimize etme adına geliştirilen ve John Stuart Mill'in 'Mantık Sistemi' (1872) adlı eserinde geliştirdiği fark ve anlaşma yöntemlerinden esinlenen iki araştırma tasarımı türü vardır. Bunlar benzer sistemler arasında 
gözlemlenen farklı siyasal sonuçları açıklayan "olabildiğince benzer sistemler tasarımı" (OBST) ve farklı sistemlerdeki benzer sonuçları açlklayan "olabildiğince farklı sistemler tasarımı" (OFST)'dir (Przeworski ve Teune 1970). John Stuart Mill'in (1843) fark yöntemine dayanan, OBST'de birbirine benzer sistemler içinde sistematik olarak farklılık gösteren ve farklı siyasi sonuçları açıklayan ana bağımsız değişken bulunmaya çalışılır. Burada önemli olan, ana bağımsız değişken boyutunda veya "anahtar nedensel değişken kategorilerine göre” (King vd., 1994: 137) farklılık gösteren, fakat kontrol etmek istenilen değişkenler boyutunda olabildiğince birbirine benzer vakalar seçilerek bağımsız değişken ve bağımlı değişkenlerde gözlenen ortak varyasyona göre nedensel çıkarımlara varılmaya çalışılır. Daha açık şekilde ifade etmek gerekirse, bu araştırma tasarımda bazı değişkenleri sabit tutmak, yani kontrol etmek için, bir dizi ortak temel özelliği (a, b ve c) paylaşan vakalar seçilir ve bu ortak değişkenler, bir vakada ortaya çıkan bağımlı değişkeni, (y) açıklamakta ilgisiz sayılır. Burada önemli olan bağımlı değişkenin ve ana bağımsız değişkenin (x) vakalar arasında değişkenlik göstermesidir. Ana bağımsız değişkenin varlığının veya yokluğunun, bir bağımlı değişkendeki farklılığı açıkladığı bu tasarım, Mill'in fark yöntemine uymaktadır.

OBST benzerlikler arasında farklılara odaklanarak sonucun farklılaşmasını araştırırken; OFST, farklılıklar arasında benzerlikleri odaklanarak benzer sonuçları açıklamaya çalışmaktadır (Przeworski ve Teune, 1970). John Stuart Mill'in belirli bir sonucu açıklamak aynı sonucu deneyimleyen vakalar seçerek bu vakalar arasında aynı olan özellikleri belirlemeye yönelik anlaşma yöntemine dayanan OFST'de birden fazla bağımsız değişken (a'dan i'ye) üzerinde farklılaşan ama ana bağımlı değişken (y) üzerinde benzeşen vakalar seçilerek hangi bağımsız değişkenin bağımlı değişkene etki ettiği bulunmaya çalışılır. Söz konusu farklılıklar aynı sonucun nedeni olarak görülemeyeceği için potansiyel değişkenler olarak kontrol edilmiş olur. Açıklanacak sonucun tüm vakalarda görülen temel bağımsız değişkenin (x) varlığından kaynaklanan bu tasarım, Mill'in anlaşma yöntemine uymaktadır. İki tasarım arasındaki temel fark, değişken setinin değiştiği ve değişmediği yerdir. OBST'de sabit tutulan tüm ülkelerde ortak olan bazı değişkenler vardır, ancak temel bağımsız değişkenler ve bağımlı değişken ülkeler arasında farklılık gösterir. OFST'de ise temel bağımsız değişken ve bağımlı değişken değişmezken, karşılaştırma yapılan ülkeleri en farklı yapan geri kalan değişkenler farklılık gösterir. Bir başka deyişle, ilk tasarım, sistemler arasındaki farkların en aza indirilmesini, ikincisi ise bu farklılıkların en üst düzeye çıkarılmasını teşvik eder (Gerring, 2007: 139). Aşağıdaki tablo, bu iki sistem arasındaki farklılıkları açıklamakta ve Mill’in yöntemlerinden hangilerine uyduklarını göstermektedir. 
Tablo 1: Araştırma Tasarımları

\begin{tabular}{|l|c|c|c|c|c|c|}
\hline Tasarım Modeli & \multicolumn{3}{|l|}{$\begin{array}{l}\text { Olabildiğince Benzer } \\
\text { Sistemler Tasarımı (OBST) } \\
\text { Mill'in fark metodu }\end{array}$} & \multicolumn{2}{l|}{$\begin{array}{l}\text { Olabildiğince Farklı Sistemler } \\
\text { Masarımı (OFST= } \\
\text { Mill'in anlaşma metodu }\end{array}$} \\
\hline Değişkenler & Vaka 1 & Vaka 2 & Vaka 3 & Vakal & Vaka 2 & Vaka 3 \\
\hline Değişken 1 & $\mathrm{a}$ & $\mathrm{a}$ & $\mathrm{a}$ & $\mathrm{a}$ & $\mathrm{d}$ & $\mathrm{g}$ \\
\hline Değişken 2 & $\mathrm{b}$ & $\mathrm{b}$ & $\mathrm{b}$ & $\mathrm{b}$ & $\mathrm{e}$ & $\mathrm{h}$ \\
\hline Değişken 3 & $\mathrm{c}$ & $\mathrm{c}$ & $\mathrm{c}$ & $\mathrm{c}$ & $\mathrm{f}$ & $\mathrm{i}$ \\
\hline $\begin{array}{l}\text { Ana Açıklayıcı } \\
\text { Değişken (ler) }\end{array}$ & $\mathrm{x}$ & $\mathrm{x}$ & $\mathrm{x}$ değil & $\mathrm{x}$ & $\mathrm{x}$ & $\mathrm{x}$ \\
\hline $\begin{array}{l}\text { Bağımlı Değişken } \\
\text { (Açıklanmak İstenen } \\
\text { Sonuç) }\end{array}$ & $\mathrm{y}$ & $\mathrm{y}$ & $\mathrm{y}$ değil & $\mathrm{y}$ & $\mathrm{y}$ & $\mathrm{y}$ \\
\hline
\end{tabular}

OBST, özellikle alan çalışmaları yapan kişiler için uygundur (Przeworski ve Teune, 1970: 33; Landman, 2008: 71). Avrupa, Asya, Afrika ve Latin Amerika gibi dünyanın belirli bir coğrafi bölgesini oluşturan ülkelerin doğası gereği benzer olmaları ve ortak tarih, dil, din, siyaset veya kültür paylaşmaları bu araştırma tasarımı için elverişli ortamı oluşturmaktadır. Przeworski ve Teune (1970) Karşılaştırmalı Sosyal Araştırma Mantığı adlı kitaplarında, ekonomik, kültürel ve siyasi özellikleri açılarından birçok benzerlikler taşıyan İskandinav ülkelerini veya iki parti sistemlerine sahip olan Anglosakson ülkelerini bu tip tasarım için prototip örnek olarak vermişlerdir. Buna rağmen, Przeworski ve Teune'un da içinde olduğu birçok karşılaştırmalı siyasetçi, olabildiğince benzer sistemler tasarımının vakalar arasında neredeyse her zaman birçok fark olacağı ve bunun da hangi farklılıkların anahtar farklılar olup olmadığının belirlenmesini zorlaştırarak bağımlı değişkenin 'aşırı belirlenmesi' sorununa yol açacağı için OFST'nin tercih edilmesini savunmaktadır.

OFST; devrimler, askeri darbeler, demokrasiye geçişler veya yeni sanayileşmiş ülkelerde "ekonomik mucizeler" gibi tanımlanmış bir sonucu açıklamaya yönelik karşılaştırmalı çalışmalarda oldukça sık kullanılmaktadır. Bu tasarımda karşımıza çıkan en önemli kısıt ise vaka seçiminin bağımlı değişken üzerinden yapılmasından kaynaklanan seçim yanlılığı ve bunun yol açabileceği yanlış çıkarım riskidir (Geddes, 1990; King vd., 1994). Bunun nedeni, bağımlı değişken üzerinden vaka seçimi yapılıp yani sadece belirli bir sonucu gösteren vakalar örnekleme dahil edilip göstermeyenler dışarıda bırakılırsa sonuçla ilişkilendirilen değişkenlerin sonucu gerçekten değiştirip değiştirmediğinin test edilemeyecek oluşudur. Bu da belirlenen neden ile gözlenen etki arasında 
yanlış çıkarımlara varılmasına yol açabilir. Örneğin, Barbara Geddes'in (1990) işaret ettiği gibi Tayvan, Güney Kore ve Singapur gibi Doğu Asya'nın yeni sanayileşmiş ülkelerinin hızlı ekonomik büyümesinin altında yatan nedenleri araştıran birçok araştırma, vaka seçimini bağımlı değişken üzerinden yaparak yani sadece hızlı ekonomik büyüme yaşayan Doğu Asya ülkeleri örneklem olarak alarak hızlı büyüme esnasında iş gücünü囚 baskı altında tutmanın ekonomik büyümeye pozitif katkısı olduğunu iddia etmişlerdir. Fakat iş gücünü囚 benzer şekilde baskı altında tutan fakat bu ülkeler gibi başarılı bir ekonomik büyüme deneyimlemeyen birçok ülke olduğu göz önüne alındığında, farklı derecelerde ekonomik büyüme yaşayan ülkelerin araştırmaya dahil edilmesi muhtemelen daha farklı çıkarımlara varılmasını yol açacaktır (134-141).

Bu sorunu miminize etmenin bir yolu vaka-içi karşılaştırma yoluyla gözlem sayısını arttırmak (Campbell 1975) ve/ya birkaç pozitif vakayı uygun negatif vakalarla kontrast olarak karşılaştırarak her iki yöntemi de birlikte kullanmaktır (Bennett ve Elman, 2006; Skocpol ve Somers 1980: 183-184; Mahoney, 2007: 34; Collier, 1991: 112; Collier ve Mahoney, 1996; Brady ve Collier 2010). Harvard Üniversitesinden Barrington Moore’un kaleme aldığı Diktatörlüğün ve Demokrasinin Toplumsal Kökenleri: Çağdaş Dünyanın Yaratılmasında Soylunun ve Köylünün Rolü (1967) adlı eseri OBST içinde Mill'in her iki yöntemini birlikte kullanan en önemli çalışmalar arasındadır. Moore, hangi tarihsel dinamiklerin farklı siyasal rejimlerin (demokratik, faşist veya komünist) ortaya çıkmasında etkili olduğunu sekiz farklı ülkeyi inceleyerek ortaya koymuştur. İngiltere, Fransa ve ABD’nin liberal demokratik sonuçların; Almanya, İtalya ve Japonya faşist sonuçların, Rusya ve Çin ise komünist sonuçların örnekleri olarak incelenmiştir. Vakalar-arası analizinde yani liberal demokrasi, faşizm ve komünizm gibi farklı siyasal sonuçlara yol açan koşulları karşılaştırırken Mill'in fark yöntemini kullanan Moore, hepsi bir tarım devrimi yaşayan benzer vakaların hangi ortak değişken yoluyla farklı bir sonucu deneyimlemediğini ortaya koymaya çalışmıştır. Eşzamanlı olarak ise vaka-içi analizinde, yani ayni siyasal sonucu deneyimleyen iki veya üç ülkeyi birbiri ile karşılaştırırken, Mill'in anlaşma yöntemini kullanan Moore, benzer vakalar arasındaki farklıkları bulmaya çalışmıştır. Moore incelediği ülkelerde modernleşmesinde izledikleri farklı siyasi yolları ya da ortaya çıkan farklı siyasal rejimleri, ticari tarımın zamanlaması ve biçimi, köylüler ve toprak ağaları arasındaki sınıf ilişkileri ve üst sınıfların ticari ve endüstriyel burjuvaziyle yaptığı ittifak türleri üzerinden açıklamıştır. Burjuvazinin isçi sınıfıyla ittifak yaparak soylu toprak sahiplerine karşı bir siyasi cephe oluşturabildiği İngiltere, Fransa ve ABD'de liberal demokrasi yerleşmiş, soylu toprak sahiplerinin burjuvaziyle ittifak yaparak isçi sınıfına karşı bir siyasi cephe oluşturduklarında ise Almanya, İtalya 
ve Japonya vakalarında görüldüğü gibi faşizm ortaya çıkmıştır. Diğer yandan, köylülerin çok baskın, soylu toprak sahipleri, burjuvazi ve isçi sınıfının ise çok zayıf olduğu bir toplumsal yapı ise Rusya ve Çin'de komünist devrime yol açmıştır. Barrington Moore'un kullandığı kategoriler ve açıklayıcı değişken kümesi aşağıdaki tabloda özetlenmiştir.

Tablo 2: Barrington Moore: Diktatörlüğün ve Demokrasinin Toplumsal Kökenleri Adlı Eserindeki Araştırma Tasarımı

\begin{tabular}{|c|c|c|c|c|}
\hline Araştırma Tasarımı & \multicolumn{4}{|c|}{ Olabildiğince Benzer Sistemler Tasarımı (OBST) } \\
\hline \multirow{2}{*}{ Bağımlı Değişken } & \multicolumn{4}{|c|}{ Modernleşme Sürecinde İzlenen Yol } \\
\hline & \multicolumn{2}{|c|}{ Liberal Demokrasi } & Faşizm & Komünizm \\
\hline $\begin{array}{l}\text { Ortak Başlangıç } \\
\text { Noktası }\end{array}$ & \multicolumn{2}{|c|}{ Tarım Bürokrasisi } & $\begin{array}{l}\text { Tarım } \\
\text { Bürokrasisi }\end{array}$ & $\begin{array}{l}\text { Tarım } \\
\text { Bürokrasisi }\end{array}$ \\
\hline Kritik Siyasal Olay & \multicolumn{2}{|c|}{ Burjuva Devrimi } & $\begin{array}{l}\text { Yukarıdan } \\
\text { Devrim }\end{array}$ & $\begin{array}{l}\text { Köylü } \\
\text { Devrimi }\end{array}$ \\
\hline $\begin{array}{l}\text { Ana Sistemik } \\
\text { Siyasal Sonuç }\end{array}$ & \multicolumn{2}{|c|}{$\begin{array}{l}\text { Demokratik Kapitalizm/ } \\
\text { Liberal Demokrasi }\end{array}$} & $\begin{array}{l}\text { Gerici Kapitalizm/ } \\
\text { Faşizm }\end{array}$ & $\begin{array}{l}\text { Komünist Dik- } \\
\text { tatörlük }\end{array}$ \\
\hline Ülkeler & $\begin{array}{l}\text { İngiltere } \\
\mathrm{ABD}\end{array}$ & Fransa & $\begin{array}{l}\text { Almanya } \\
\text { Japonya }\end{array}$ & $\begin{array}{l}\text { Rusya } \\
\text { Çin }\end{array}$ \\
\hline \multicolumn{5}{|l|}{ Ana Değişkenler } \\
\hline Burjuva Dürtüsü & Güçlü & Güçlü & Orta & Güçsüz \\
\hline Ticari Tarım Tipi & $\begin{array}{l}\text { Piyasa- } \\
\text { odakl1 }\end{array}$ & $\begin{array}{l}\text { Emek- } \\
\text { baskı1c1 }\end{array}$ & İşçi-baskııı & İşçi-baskııı \\
\hline $\begin{array}{l}\text { Çiftçinin Devrimci } \\
\text { Potansiyeli }\end{array}$ & Düşük & Yüksek & Düşük & Yüksek \\
\hline Vaka-İçi Yöntem & \multicolumn{2}{|c|}{ Anlaşma Yöntemi } & Anlaşma Yöntemi & $\begin{array}{l}\text { Anlaşma } \\
\text { Yöntemi }\end{array}$ \\
\hline $\begin{array}{l}\text { Vakalar-Arası } \\
\text { Yöntem }\end{array}$ & \multicolumn{4}{|c|}{ Fark Yöntemi } \\
\hline Kaynak & \multicolumn{4}{|c|}{ Skocpol, 1994: 32'den adapte edilmiştir. } \\
\hline
\end{tabular}


Harvard Üniversitesi'nden Barrington Moore'un öğrencisi olan Theda Skocpol'un Devletler ve Toplumsal Devrimler: Fransa, Rusya ve Çin'in Karşılaştırmalı Analizi (1979) adlı kitabı ise OFST içinde Mill'in hem anlaşma hem de fark yöntemini kullanan en meşhur örnekler arasındadır. Skocpol, bu çalışmasında, siyasal, demografik, ekonomik, sosyal, etnik, dinî, kültürel ve tarihi olarak birbirinden çok farklı özellikler gösteren Fransa (1789), Rusya (1917) ve Çin (1911) vakalarını ele alarak tüm bu farklılıklara karşın neden bu üç ülkede modern tarihin en önemli üç büyük devriminin yaşandığı sorusuna yanıt aramıştır. Araştırma tasarımı dolayısı ile OFST üzerine kurulmuştur. Bu tasarım içerisinde Mill'in anlaşma ve farklılık mantığını, gerekli ve yeterli potansiyel nedenleri ortadan kaldırmak için araçlar olarak yeniden düzenleyen Skocpol, Mill'in anlaşma yöntemini gerekli potansiyeller nedenleri, fark yöntemini ise potansiyel yeterli nedenleri kontrol etmek için kullanmıştır. Birbirinden farklı siyasi ekonomik ve sosyal sistemleri olan bu vakalardaki farklılıkları Mill'in anlaşma mantığına dayanarak sonucu açıklamada etkisiz sayan Skocpol, devlet çöküşü ve köylü isyanını toplumsal devrimlerin gerçekleşmesi için iki gerekli potansiyel neden olarak ortaya koymuştur. Bu üç pozitif vakayı karşılaştırılabilir koşulları olan ancak sosyal devrimlerin olmadığı veya başarısız olduğu devrim öncesi Rusya (1905), İngiltere, Almanya, Prusya ve Japonya gibi negatif vakalarla Mill'in fark yöntemini uygulayarak karşılaştıran Skocpol, pozitif vakalarda gözlemlenen devrimin gerçekleşmesi için gerekli olan nedenlerin aynı zamanda yeterli nedenler olup olmadığını sınamıştır. Skocpol'un negatif vaka incelemesi, İngiltere ve Japonya`da köylü ayaklanmaları olmadan devlet çöküşleri yaşandığını, Almanya 1848،deki devlet çöküşünün geçici ve köylü ayaklanmaları bölgesel olarak sınırlı olduğunu ve Rusya'da 1905'deki devlet çöküşünün kısa sürede tersine dönen geçici bir çöküş olduğunu ortaya koyarak, devlet çöküşü ve köylü ayaklanmalarının birlikte yaşanmasının sosyal devrimlerin yaşanması için gerekli ve yeterli koşullar olduğu sonucuna varmasını sağlamıştır (Skocpol, 1979:189).

Tablo 3: Skocpol'un Devletler ve Toplumsal Devrimler Adlı Çalışmasının Araştırma Tasarımı

\begin{tabular}{|l|l|c|c|c|c|c|c|c|}
\hline $\begin{array}{l}\text { Araştırma } \\
\text { Tasarımı }\end{array}$ & \multicolumn{6}{|l|}{ Olabildiğince Farklı Sistemler Tasarımı } \\
\hline Yöntem & \multicolumn{6}{|l|}{ Anlaşma Yöntemi } & \multicolumn{6}{|l|}{ Fark Yöntemi } \\
\hline Vakalar & Fransa & Rusya & Çin & İngiltere & $\begin{array}{l}\text { Rusya } \\
(1905)\end{array}$ & $\begin{array}{l}\text { Prusya } \\
\text { Almanya } \\
(1807)\end{array}$ & $\begin{array}{l}\text { Almanya } \\
(1848)\end{array}$ & Japonya \\
\hline Bağımsız Değişkenler \\
\hline $\begin{array}{l}\text { Uluslararası } \\
\text { baskı }\end{array}$ & $\mathrm{E}$ & $\mathrm{E}$ & $\mathrm{E}$ & $\mathrm{H}$ & $\mathrm{H}$ & $\mathrm{E}$ & $\mathrm{H}$ & $\mathrm{E}$ \\
\hline
\end{tabular}




\begin{tabular}{|c|c|c|c|c|c|c|c|c|}
\hline $\begin{array}{l}\text { Örgütlü ve ba- } \\
\text { ğımsız egemen } \\
\text { sınıfın devlet } \\
\text { içindeki gücü }\end{array}$ & E & $\mathrm{H}$ & E & E & $\mathrm{H}$ & $\mathrm{H}$ & $\mathrm{H}$ & $\mathrm{H}$ \\
\hline $\begin{array}{l}\text { Zengin Tarım } \\
\text { Ekonomisi }\end{array}$ & E & $\mathrm{H}$ & $\mathrm{H}$ & E & E & E & E & $\mathrm{E}$ \\
\hline $\begin{array}{l}\text { Çiftçi özerkliği } \\
\text { ve otonomisi }\end{array}$ & E & $\mathrm{E}$ & $\mathrm{H}$ & $\mathrm{H}$ & E & $\mathrm{H}$ & $\mathrm{H}$ & $\mathrm{H}$ \\
\hline Devlet çöküu̧üü & $\mathrm{E}$ & $\mathrm{E}$ & E & $\mathrm{E}$ & $\mathrm{H}$ & $\mathrm{H}$ & E & E \\
\hline $\begin{array}{l}\text { Çiftçi } \\
\text { Ayaklanması }\end{array}$ & E & E & $E^{*}$ & $\mathrm{H}$ & E & $\mathrm{H}$ & $\mathrm{H}$ & $\mathrm{H}$ \\
\hline $\begin{array}{l}\mathrm{E}=\mathrm{EVET} \\
\mathrm{E}^{*}=1930 \text { 'dan sonr } \\
\mathrm{H}=\text { Hayır }\end{array}$ & Eve & & & & & & & \\
\hline $\begin{array}{l}\text { Kaynak: Skocpol, } 19 \\
\text { fından uyarlanmışt }\end{array}$ & 0 & 8 & & & & & $4^{\prime} d$ & $r$ tara- \\
\hline
\end{tabular}

\section{Karşılaştırmalı Perspektiften Tek Vaka Çalışmaları}

Vaka analizi, bir fenomen sınıfının tek bir örneğinin belirli bir zaman ve mekânda incelenmesini ifade eden bir araştırma yöntemidir (Gerring, 2004: 342). Sartori (1991:252) ve King vd.'nin (1994) de dahil olduğu birçok karşılaştırmalı siyaset uzmanı, karşılaştırmanın benzer veya farklı bir çeşitlilikten en az iki vakayı içermesi gerektiğini iddia ederek tek-vaka analizlerinin karşılaştırmalı yöntem altında değerlendirilemeyeceğini fakat karşılaştırmalı değer taşıyabileceğini savunmaktadırlar. Aynı tümevarımsal çıkarım mantığının, yani bir hipotezin gözlemlenebilir bir sonucu olarak gerçekleri toplama vurgusunun, nitel ve nicel analizin temelini oluşturduğunu ifade eden King vd. (1994), tek vaka analizlerinden elde edilen tek gözlemle hipotezlerin test edilemeyeceğini çünkü tek bir gözlemde sadece tek bir çıkarımın test edebileceğini ileri sürmektedirler. Nitekim, birkaç vaka analizinde de karşımıza çıkan değişkenleri kontrol edebilecek sayıda vakaya sahip olunmaması, aşırı belirlenim ve seçim yanlılığı sorunları tek ülke çalışmalarında daha büyük bir problemdir.

Diğer yandan, tek ülkeli vaka analizini, 'teori inşa sürecinin tüm aşamalarında” değerli bulan Eckstein (1975:80), bu çalışmaları belirli tedavilerin etkilerinin yoğun bir şekilde incelendiği tıp alanındaki klinik çalışmalara benzetir ve bu çalışmalardan hem hipotezler geliştirilebileceğini hem de hipotezlerin test edilebileceğini savunur. Doğan ve Pelassy (1990) benzer 
şekilde, genelleştirmeyi hedefleyen bir tek ülke analizinin araştırmacının vakasını daha büyük teorik veya kavramsal kaygılar ışığında incelemeye odaklanmasını gerektirdiğinden karşılaştırmalı siyaset teorisine katkı sunabileceğini belirtir. Daha geniş bir teorik araştırma girişiminin parçası olarak yapılan tek-ülkeli vaka analizleri karşılaştırmalı siyasetin en önemli ve yenilikçi çalışmalar arasındadır (Pepinsky, 2019). Aslında, tek ülke üzerine karşılaştırmalı siyaset etiketiyle basılmış, diğer alanlardan çok daha fazla kitap vardır. Amerika'da Demokrasi (Tocqueville, 1835); Kim Yönetiyor? (Dahl, 1961); Uzlaşı Politikaları (Lijphart, 1968); Modernleşme ve Bürokratik Otoriterizm (O’Donnell, 1973); Çatışmacı Fransız (Tilly, 1986); Demokrasi ve Kargaşa (Tarrow, 1989); Demokrasiyi Çalıştırmak (Putnam, 1993) gibi kitaplar, karş1laştırmalı siyaset disiplinin teorik olarak gelişmesine önemli ölçüde hizmet eden tek-ülkeli vaka çalışmaları arasındadır. Peki, tek vaka çalışmaları hangi koşullar altında karşılaştırmalı olarak nitelendirilebilir?

Öncelikle, vakalar karşılaştırmalı bir bağlam içine yerleştirilmeli, araştırmanın analitik araçları karşılaştırmalı siyaset literatüründen gelmeli, vaka seçimi araştırmanın hedefine uygun olarak yapılmalı ve çalışmanın sonucunda elde edilen bulguların, mevcut karşılaştırmalı tipolojiyi veya teoriyi gözden geçirmek veya genişletmek için yapı taşları niteliğinde olduğu gösterilmelidir. Yukarıdaki çalışmaların tümü, sonraki tek ülke ve karşılaştırmalı çalışmalarda uygulanan ve test edilen yeni kavramlar ve genellemeler formüle eden çalışmalardır. Dolayısıyla, “örtük” bir karşılaştırma yöntemi izleyen tek ülkeli çalışmalar bile eğer "daha geniş teorik ve kavramsal bir çerçeve” göz önünde bulundururlarsa karşılaştırmalı değer taşıyabilir (Verba, 1967). Örtük karşılaştırmalar, eldeki tek vakayı yorumlamak ve bağlamsallaştırmak için mevcut tipolojileri ve sınıflandırmaları bir kıstas olarak kullanır. Ragin (1987), tek bir ülkede yoğunlaşan birçok alan uzmanının seçtikleri vakayı kendi ülkeleriyle veya hayali veya teorik olarak belirleyici bir ideal-tipik vaka ile örtük olarak karşılaştırdıklarını iddia etmektedir. Ünlü Fransız sosyolog ve siyaset bilimci Alexis de Tocqueville 'in Amerika'da Demokrasi (1838) ve Eski Rejim ve Fransiz Devrimi (1856) adlı meşhur çalışmaları örtük ikili karşılaştırmanın klasik örnekleri arasındadır. Richard Rose'un (1991: 454) “dışa dönük vaka” çalışması olarak adlandırdığı bu çalışmalarda, Tocqueville; ABD ve Fransa vakalarını Mill'in fark yöntemini kullanarak örtük bir şekilde karşılaştırarak özgürlük, toplumsal eşitlik ve demokrasi gibi genel kavramlar hakkında başka vakalarda test edilebilecek genellemeler üretmiştir (Richter, 1969).

Seçtikleri vakaya ve uyguladıkları araştırma tasarımlarına bağlı olarak karşılaştırmalı siyaset alt-disiplinin bilimsel gelişmesine farklı şekillerde katkı sunan çeşitli vaka analiz türleri vardır. Lijphart teorik olmayan, yorumlayıcı, 
hipotez üreten, teoriyi doğrulayan, teoriyi bilgilendiren ve sapkın vaka olmak üzere (1971: 691- 693), Eckstein ise yapılandırıc1-idiografik, disiplinli-yapılandırıc1, sezgisel, güvenilirlik probu ve önemli vaka olmak üzere (1975: 96123) altı tür vaka çalışmasının karşılaştırmalı siyaset teorisinin gelişimine potansiyel katkı sunabileceğini değerlendirmişlerdir. Tümevarımsal veya teori güdümlü olan ve belirli bir vakayı tanımlamayı, açıklamayı veya yorumlamayı amaçlayan idiografik vaka çalışmaları sundukları derin betimsel analiz ile genelleme yapabilmek için hammadde sağlar ama kendisi genelleştirebilir önermeler üretemez. Fakat vaka seçimine ve araştırma tasarımına bağlı olarak, tek vaka çalışmaları teori gelişimine farklı şekillerde katkı sunar. Örneğin, mevcut bir teorinin geçerliliğini doğrulamak veya yanlışlamak, yani hipotezleri test etmek için kritik bir vaka (crucial case) seçilebilir. Kritik vakalar, tek bir vakanın bile, belli koşulları sağladığı sürece, yerleşik teorileri sarsabilecek ve yeni teorilere ve kavramsal keşiflere yol açabilecek olan vakalardır. "En olası vaka (most likely case) çalışmaları" ve "en az olası (least likely case) vaka çalışmaları” olmak üzere iki tür kritik vaka çalışması vardır (Eckstein, 1975: 118). En olası vaka çalışmaları belli bir konuda ele alınan bir teorinin tahminlerinin gerçekleşme olasılığının en yüksek olduğu vakanın araştırılmasıdır. Eğer ele alınan teorilerinin tahminleri en olası vakada bile gerçekleşmiyorsa, bu durum o teori için büyük bir eksikliğe işaret eder ve teorinin inandırıcılığı ciddi şekilde zarar alır. En az olası vaka çalışmaları, en olası vaka çalışmalarının tam tersine, belli bir konuda ele alınan bir teorinin tahminlerinin gerçekleşme olasılığının en düşük olduğu vakanın araştırılmasıdır. Eğer böylesi bir vakada bile ilgilenilen teorinin tahminleri gerçekleşiyorsa, diğer tüm vakalarda da gerçekleşme olasılığı yüksektir. Bu koşulda ilgilenilen teorinin analitik gücü desteklenmiş olur. Dolayısı ile, kritik vaka analizi belirli bir teorinin en az elverişli olduğu durumda bile işlediğini göstererek diğer tüm koşullarda da geçerli olacağını ortaya koyarak bir teoriyi doğrulayabilir veya en olası vakada bile işlemediğini göstererek söz konusu teorinin gözden geçirilmesine neden olabilir). Karşılaştırmalı siyasetin hipotez geliştirme amacına hizmet eden bir başka önemli tek vaka-çalışması ise 'sapkın vaka' (deviant case) araştırmasıdır. Mevcut normlara aykırı olan ve mevcut herhangi bir teoriye veya model uymayan sapkın vakalar, anormalliklerin çalışması olarak da nitelendirilebilir (Elman ve Elman 2002; Gerring ve Cojocaru, 2016). Sapkın vaka analizleri, atipik vakayı açılamak için genelleştirilebilir hipotezler üretebilir veya bir teorinin kapsam koşullarında bir düzeltmeye yol açabilir (Gerring ve Cojocaru, 2016: 399; Mahoney, 2007: 125; Mayer, 1989: 44). Yeni bir kategori yaratan veya genel eğilimleri doğrulayan “örnek” (exemplary) vaka analizleri veya gelecekte tipik olması beklenen bir 
vakayı ifade eden prototipik vaka analizleri karşılaştırmalı siyasette yeni kavramlar ve kategoriler inşa ederek teorileri ve fikirleri formüle etmenin yapı taşını oluşturur (Hague vd., 2016: 94-95). Dolayısı ile vaka seçimine bağlı olarak, tek ülke çalışmaları bağlamsal bir açıklama sağlar, yeni kavramlar geliştirir, hipotezler oluşturur, teorileri doğrular ve yanlışlar ve uluslararası karşılaştırma yoluyla tanımlanan sapkın ülkelerin varlığını açıklar (Eckstein 1975; Landman 2008; Yin 2013; George ve Bennett 2005).

Tek-ülkeli vaka çalışmalarının daha güçlü ve genellenebilir çıkarımlarda bulunması vaka-içi kesitsel veya zamana göre karşılaştırma yaparak gözlem sayılarını arttırması yolu ile olur. Vaka-içi karşılaştırmalar, bağımsız değişkenin farklılaşmasına imkân tanıdığı için nedensel analizin güçlendirilmesine yardımcı olur ve aynı zamanda seçim yanlılığı sorununu da azaltır (Collier ve Mahoney, 1996). Vaka-içi analizlerinde görülen "analitik anlatılar" (Bates vd., 1998), "nedensel süreç izleme” (Collier, 2011), “örüntü eşleştirme” (Campbell, 1975; Yin, 1984) ve "uygunluk" (George ve Bennett, 2005: 181-203) gibi çeşitli vaka-içi analiz yöntemleri ile başlangıçta tek bir gözlem birimi olarak ele alınan vakanın çoklu özelliklerine karşı hipotezler test edilebilirken, "yol bağımlılı̆̆ı" (Pierson, 2000;2004; Mahoney, 2000; 2001), "kritik olaylar” (Collier ve Collier, 1991) ve "kesintili denge" (Baumgartner vd., 2009) gibi kavramlara dayanmak, genel yasalar veya istatistiksel ilişkiler yerine nedensel zincirler ve mekanizmalara dayanan bir açıllama sağlar (George \& Bennett, 2005; Bennett ve Elman, 2006). Nedensel mekanizma, bağımlı değişken üzerinde açıklayıcı değişken yolu ile etki eden nedensel süreç veya ara değişkeni ifade etmektedir. Nedensel mekanizmanın yeterliliği veya geçerliliği, süreç izleme ve süreç doğrulama gibi yöntemlerle test edilmektedir. Süreç izleme, nedensel bir mekanizmanın (süreç veya ara değişkenin) bağımlı değişken üzerinde nasıl ve ne zaman bir etki yarattığını ortaya koymak için olaylar sırasının analizine dayanmaktadır. Süreç doğrulaması ise tespit edilen nedensel sürecin olaylar dizisine uyup uymadığını olayların ortaya çıkarılması ve tanımlanan nedensel sürecin olayların sırasına uyup uymadığına bakılması anlamına gelir. Bu kriterleri karşılayan tek-vaka çalışmaları idiografik veya betimleyici çalışmalardan bir adım öne çıkarak "açıklayıcı" çalışma kategorisine dahil olabilir (George ve Bennett, 2005; Flyvbjerg 2006).

İtalya'nın kuzey ve güney bölgelerindeki yerel yönetimlerin siyasi ve ekonomik performans belirleyicilerini araştıran Robert Putnam'ın (1993) Demokrasiyi Çalıştırmak: Modern İtalya'da Sivil Gelenekler adlı çalışması vaka-içi analiz yöntemini kullanarak çıkarımlarını Büyük N'den yapan açıklayıcı tek-ülkeli vaka çalışmalarının en iyi bilinen örnek arasındadır. İtalyaının yirmi idari bölgesinde yirmi yıl boyunca gözlemlenen siyasi ve ekonomik 
performans varyasyonlarını incelemek için araştırmasında hem nitel hem de nicel verileri kullanan Putnam; yirmi yıl boyunca, bölgesel performansı ustaca geliştirilmiş nicel ölçütlere göre değerlendirmiş, kurumsal performansta kesitsel ve zamansal değişimin nedenlerini değerlendirmek için bölgesel meclis üyeleri ve topluluk liderleriyle görüşmüş, sayısız kitle ve elit anketi gerçekleştirmiş ve vaka-içi analiz ve süreç-takibi yöntemlerini uygulayarak altı İtalyan bölgesinin tarihini analiz etmiştir. Mill'in fark yöntemini kullanarak birbirine benzeyen vakalar arasında sonuçta oluşan farklılığı açıklayan farklılıklara odaklanan yani OBST kullanan Putnam, her bölgedeki sivil katılım ve sivil yeterlilik konularında kanıtlanabilir farklılıklar nedeniyle aynı reformların farklı bölgesel politika performanslarına yol açtığını gözlemlemiştir. Kuzey İtalya'daki Rönesans şehir-devletlerinden gelen sivil geleneğin ortaya çıkardığı yüksek düzeydeki sosyal sermayenin Güney İtalya geleneğinde eksik olduğunu gözlemleyen Putnam, Kuzey ve Orta İtalya'daki dernekleşme deneyiminin kişilerarası güveni ve demokratik yerel yönetimleri geliştirirken; Güneyde, benzer deneyimin olmamasından ötürü daha az başarılı olduklarını ortaya koymuştur. Putnam, bu çalışmasında başarılı bir demokratik toplumun vatandaşların sivil ilişkilerinin bir sonucu olarak topluluklarına ne kadar katıldıkları ve yatırım yaptıkları oranında var olduğunu ortaya koyarak disiplinde hâlâ canlı bir tartışma konusu olmayan devam eden 'sosyal sermaye' kavramını ön plana taşımış ve sosyal sermaye, demokrasi ve yönetişim performansları arasındaki ilişkilere yönelik diğer vakalarda test edilebilecek yeni hipotezler üreterek karşılaştırmalı siyasetteki teori gelişimine katkı sunmuştur. Aşağıdaki tablo, karşılaştırmalı siyasette kullanılan yöntemlerin karşılaştırmalı analizini özetleyerek sunmaktadır.

Tablo 4: Karşılaştırmalı Siyasette Kullanılan Yöntemlerin Karşılaştırmalı Analizi

\begin{tabular}{|c|c|c|c|}
\hline & $\begin{array}{l}\text { Birçok Vaka (Large-N) } \\
\text { Analizi }\end{array}$ & $\begin{array}{l}\text { Birkaç Vaka Small-N) } \\
\text { Analizi }\end{array}$ & Tek Vaka $(n=1)$ Analizi \\
\hline & Genelleştirmek & Açıklamak & Anlamak \\
\hline Amaç & $\begin{array}{l}\text { Bir örneklemden } \\
\text { toplanan verileri ölçer, } \\
\text { hipotezleri test eder ve } \\
\text { sonuçları genelleştirir. }\end{array}$ & $\begin{array}{l}\text { Bir olgunun ortaya çıkı- } \\
\text { şındaki temel neden ve } \\
\text { motivasyonları açıklar. }\end{array}$ & $\begin{array}{l}\text { Bir olgunun ortaya } \\
\text { çıkışındaki temel neden } \\
\text { ve motivasyonları an- } \\
\text { latır. }\end{array}$ \\
\hline \multirow[b]{2}{*}{$\begin{array}{l}\text { Temel } \\
\text { Yöntem }\end{array}$} & Tümdengelim & Analitik Tümevarım & Yorumlama \\
\hline & $\begin{array}{l}\text { Teoriden türetilen } \\
\text { hipotezleri verilerle test } \\
\text { eder, onaylar. }\end{array}$ & $\begin{array}{l}\text { Verilerden hipotez ve } \\
\text { teoriler oluşturur. }\end{array}$ & $\begin{array}{l}\text { Verilerden hipotezler } \\
\text { üretir, teori doğrular } \\
\text { veya yanlışlar. }\end{array}$ \\
\hline
\end{tabular}




\begin{tabular}{|c|c|c|c|}
\hline $\begin{array}{l}\text { Karşılaştırma } \\
\text { Mantığı }\end{array}$ & $\begin{array}{l}\text { Belirli bir iddia, hipotez } \\
\text { veya teoriyi doğrulama } \\
\text { veya yanlışlama amacı } \\
\text { ile bir dizi vakayı karşı- } \\
\text { laştırır. }\end{array}$ & $\begin{array}{l}\text { Daha güçlü teorik açık- } \\
\text { lama inşa etme amacı } \\
\text { ile vakalar kullanılır; } \\
\text { her bir vaka adım adım } \\
\text { genel teorinin geliştiril- } \\
\text { mesine katkıda bulunur. }\end{array}$ & $\begin{array}{l}\text { Vakanın daha iyi anlaşıl- } \\
\text { ması için farklı vakaları } \\
\text { ve/ya genel teorileri } \\
\text { kullanılır. }\end{array}$ \\
\hline $\begin{array}{l}\text { Çalışmanın } \\
\text { Türüi }\end{array}$ & $\begin{array}{l}\text { Test-Edici, Genelleyici } \\
\text { Bilimsel, Kesin }\end{array}$ & Açıklayıcı, Keşifçi & Betimleyici, yorumlayıc1 \\
\hline $\begin{array}{l}\text { Toplanan Veri } \\
\text { Tipi }\end{array}$ & İstatistiksel, sayısal & Nitel & Nitel \\
\hline $\begin{array}{l}\text { Veri Toplama } \\
\text { Yöntemi }\end{array}$ & $\begin{array}{l}\text { Deneyler, denetimler, } \\
\text { anket araştırması, dere- } \\
\text { celendirme ölçekleri }\end{array}$ & $\begin{array}{l}\text { Röportajlar, odak grup- } \\
\text { ları, vaka çalışmaları, } \\
\text { gözlem }\end{array}$ & $\begin{array}{l}\text { Röportajlar, odak grup- } \\
\text { ları, vaka çalışmaları, } \\
\text { gözlem }\end{array}$ \\
\hline $\begin{array}{l}\text { Çalışmanın } \\
\text { Odak Noktası }\end{array}$ & $\begin{array}{l}\text { Değişkenler arası } \\
\text { ilişkiler }\end{array}$ & Nedensel ilişki & $\begin{array}{l}\text { Vakanın içinde bulduğu } \\
\text { bağlam }\end{array}$ \\
\hline $\begin{array}{l}\text { Kontrol } \\
\text { Mekanizması }\end{array}$ & İstatiksel Kontrol & $\begin{array}{l}\text { Seçerek Kontrol } \\
\text {-OBST } \\
\text {-OBFS }\end{array}$ & $\begin{array}{l}\text { Yoğun, ideografik, } \\
\text { yol- bağımlı ve } \\
\text { yapılandırıcı analiz } \\
\text {-Sapkın Vaka } \\
\text {-Kritik Vaka } \\
\text {-En Az Olası Vaka } \\
\text {-En Olası Vaka }\end{array}$ \\
\hline Avantajları & $\begin{array}{l}\text { Geniş kapsam } \\
\text { Sınırlı seçim yanlılığı } \\
\text { Teori inşasına katkı sağ- } \\
\text { layan güçlü çıkarımlar } \\
\text { Sapkın ülkeleri belirleme }\end{array}$ & $\begin{array}{l}\text { Kavramsal Derinlik } \\
\text { Nedensellik } \\
\text { Teori inşası } \\
\text { Konfiguratif ve tarihsel } \\
\text { makro analiz } \\
\text { Nedensel Süreç Analizi } \\
\text { Vaka içi Analiz } \\
\text { Alan Çalışması }\end{array}$ & $\begin{array}{l}\text { Kavramsal derinlik } \\
\text { Bağlamsal tanımlama } \\
\text { Vaka içi Analiz } \\
\text { Süreç Analizi }\end{array}$ \\
\hline Dezavantajları & $\begin{array}{l}\text { Yüksek derecede } \\
\text { soyutlama } \\
\text { Kavramsal esneme } \\
\text { Geçersiz ölçüler } \\
\text { Veri sinırlllığı } \\
\end{array}$ & $\begin{array}{l}\text { Daha az güvenli } \\
\text { çlkarımlar } \\
\text { Seçim yanlılığı }\end{array}$ & $\begin{array}{l}\text { Güvensiz çıkarımlar } \\
\text { Seçim yanlılığı }\end{array}$ \\
\hline Gereksinim & $\begin{array}{l}\text { Matematik ve Bilgisayar } \\
\text { Eğitimi }\end{array}$ & $\begin{array}{l}\text { Dil Eğitimi } \\
\text { Saha araştırması }\end{array}$ & $\begin{array}{l}\text { Dil eğitimi } \\
\text { Alan araştırması }\end{array}$ \\
\hline Kaynak & \multicolumn{3}{|c|}{$\begin{array}{l}\text { Lim, 2010: s.21; Hague vd., 2016:97 ve Landman, 2008:47'den yazar tarafından } \\
\text { yarlanmıştır. }\end{array}$} \\
\hline Not & \multicolumn{3}{|c|}{$\begin{array}{l}\text { Bu yöntemler arasında çok fazla çakışma vardır, dolayısıyla bu değerlendirme- } \\
\text { ler mutlaktan ziyade eğilimler olarak görülmelidir. }\end{array}$} \\
\hline
\end{tabular}




\section{Sonuç}

Bu çalışma siyaset biliminin merkezi bir alt-disiplini olarak ele aldığı karşılaştırmalı siyasetin tematik, işlevsel ve yöntemsel boyutlarını sırasıyla mercek altına alarak Türkçe karşılaştırmalı siyaset literatürünün ve bilgi birikiminin oluşmasına katkı sunmayı amaçlamıştır. Bu makale bu konudaki eksikliğin giderilmesine katkı sunmak için karşılaştırmalı siyasetin diğer alt-alanlar ile ilişkisinin karşılaştırılması ile başlamıştır. Siyasal sistemler, aktörler ve süreçler arasındaki benzerlik ve farklılıkları tanımlamaya, açıklamaya ve tahmin etmeye çalışan karşılaştırmalı siyasetin, ana tema olarak modern kapitalist dünyanın kökenlerini açıklama ve geleceği yansıtma sorununu aldığı ve yeni kavramlar, sınıflandırmalar ve tipolojiler geliştirme, hipotez test etme, genellemeler ve teoriler inşa etme gibi çeşitli işlevleri yerine getirdiği vurgulanmıştır. Karşılaştırmalı siyasetin yöntem boyutuna odaklanan dördüncü bölüm, geleneksel olarak birkaç vakanın (Küçük-N) nitel analizi ile özdeşleştirilen karşılaştırmalı yöntemin, değişkenlerin kontrolünü sistematik ve kasıtlı vaka seçimi yoluyla sağladığını ve orta seviyede kavramsal soyutlama kullandığını vurgulamıştır. Bu bağlamda, birçok değişken ve az vaka sayısından dolayı hipotezleri test etmek için çok vakanın incelendiği istatistiksel yöntemden daha zayıf, vaka analizinden ise daha güçlü kontrol sağlayan, karşılaştırmalı yöntemin en önemli kısıtının vaka sayısından daha fazla değişkene sahip olması olduğu vurgulanmıştır. Bu kısıtlara rağmen sistematik karşılaştırmaya izin veren karşılaştırmalı yöntemin en benzer sistem tasarımı veya en farklı sistem tasarımı ile bağımsız değişkenlerin kontrolünü sağlayarak çok değişkenli etkileşimi ve değişkenler arasındaki çoklu nedensel yapılanmayı açıklayabilecek nitelikte bir yöntem olarak değerlendirilmiştir.

Geleneksel anlayış karşılaştırmalı yöntemi birkaç vaka analizi ile özdeşleştirse de, bu çalışma, vaka sayısı ne olursa olsun bir çalışma karşılaştırma yoluyla genellemeler kullanıyor veya inşa ediyorsa, karşılaştırmalı siyaset şemsiyesi altında sınıflandırması düşüncesinden yola çıkarak, genellikle istatiksel yöntemlerin kullanıldığı birçok vaka (Büyük $N$ ) analizlerini ve nitel yöntemlerin kullanıldığı tek vaka çalışmalarını da karşılaştırmalı siyasetin diğer yöntemsel stratejileri olarak incelemiştir. Çok fazla sayıda vaka üzerinde birkaç değişken arasındaki ilişkiyi aynı anda inceleyebilmeleri sebebiyle genelleme konusunda avantaja sahip olan birçok vaka analizlerinin daha fazla küresel uygulanabilirliğe sahip güçlü çıkarımlar yapma, diğer araştırmacllar tarafından kontrol edilebilen standart istatiksel teknikler kullanarak büyük miktarlarda verilerin kesin ilişkisel analizini sunma ve 'sapkın' vakaları veya 'aykırı değerleri' tanımlama yeteneği gibi avantajları olduğu fakat derin 
bağlamsal ve kavramsal analiz ve karmaşık nedensellik açıklaması açılarından zayıf kaldığı vurgulanmıştır. Birçok ve birkaç vaka analizlerine göre daha az güvenli çıkarımlar sağlayan tek vaka çalışmalarının genellikle kapsamı ve genellenebilirliği kısıtlı araştırmalar olsa da bugün hâlâ karşılaştırmalı siyasette yoğun ve yaygın olarak kullanıldığı vurgulanmıştır. Tek vaka çalışmalarının doğası gereği karşılaştırmalı olamayacağını iddia edenlerin aksine bu makale, tek vaka çalışmalarının vaka seçimine bağlı olarak veya örtük karşılaştırma veya kesitsel ve/ya zamana göre vaka-içi analiz yoluyla gözlem sayılarını arttırarak diğer ülkeler için geçerli kavramlar geliştirebileceği, bağlamsal açıklama sağlayabileceği, hipotezler oluşturabileceği, teorileri doğrulayabileceği ve yanlışlayabileceği üzerinde durulmuştur. Süreç analizi, örüntü eşleştirme, süreç izleme ve nedensel anlatı gibi çeşitli vaka içi analiz yöntemleri ile bu çalışmaların nedensel çıkarımlarının gücünü arttırma imkânları olduğu vurgulanmıştır.

\section{Kaynakça}

Almond, Gabriel A. (1966). Political Theory and Political Science. American Political Science Review 60 (4), 869-79.

Almond, Gabriel A. ve Verba, Sidney (1963). The Civic Culture: Political Attitudes and Democracy in Five Nations. Princeton, N.): Princeton University Press.

Aristoteles (2017). Politika Bütün Yapıtları 3. Çev. F Akdemir, Istanbul: Say Yayınları

Bates, Robert H. (1996). The Death of Comparative Politics?. APSA-CP: Newsletter of the APSA Organized Section in Comparative Politics, 7 (2): 1-2.

Bates, Robert H vd. (der) (1998). Analytic Narratives. Princeton, NJ: Princeton University Press.

Baumgartner Frank R. vd. (2009). Punctuated Equilibrium in Comparative Perspective. American Journal of Political Science, 53: 603-620.

Bennett, Andrew ve Elman, Colin (2006). Qualitative Research: Recent Developments in Case Study Methods. Annual Review of Political Science, 9, 455-476.

Berger, Suzanne ve Dore, Ronald (der) (1996). National Diversity and Global Capitalism. Ithaca, NY: Cornell University Press.

Bernhard, Michael (2009). Methodological Disputes in Comparative Politics. Comparative Politics, 41(4), 495-515.

Boix, Carles (2011). Democracy, Development, and the International System. American Political Science Review, 105 (4), 809-828.

Boyer, Robert ve Drache, Daniel (der) (1996). States against Markets: The Limits of Globalization. London and New York: Routledge.

Brady, Henry E. ve Collier, David (2010). Rethinking Social Inquiry: Diverse Tools, Shared Standards. Lanham, Md: Rowman \& Littlefield Publishers.

Burawoy, Michael (1989). Two Methods in Search of Science: Skocpol versus Trotsky. Theory and Society, 18 (6), 759-805.

Campbell, Donald T. (1975). Degrees of Freedom and the Case Study. Comparative Political Studies, 8(2), 178-193. 
Caramani, Daniele (2017). Introduction to Comparative Politics. İ̧inde D Caramani (der), Comparative Politics, Oxford: Oxford University Press, 1-18.

Cheibub, Jose A. ve Limongi, Fernando (2002). Democratic Institutions and Regime Survival: Parliamentary and Presidential Democracies Reconsidered. Annual Review of Political Science, 5, 151-79.

Clark, William R. vd. (2018). Principles of Comparative Politics. Thousand Oaks: Sage.

Coates, David (2000). Models of Capitalism. Cambridge: Polity Press.

Collier D (1991). The Comparative Method: Two Decades of Change. İçinde D Rustow ve K P Erickson (der), Comparative Political Dynamics: Global Research Perspectives, New York: HarperCollins Publishers, 7-31.

Collier, David (1993). The Comparative Method. İçinde A W Finifter (der), Political Science: The State of the Discipline II, Washington, DC: American Political Science Association, 105-19.

Collier, David (2011). Understanding Process Tracing. PS: Political Science and Politics, 44 (4), 823-830.

Collier, David vd. (2008). Typologies: Forming Concepts and Creating Categorical Variables. Içinde J M Box-Steffensmeier vd. (der), Oxford Handbook of Political Methodology, Oxford: Oxford University Press, 152-173.

Collier, David vd. (2012). Putting Typologies to Work: Concept Formation, Measurement, and Analytic Rigor. Political Research Quarterly, 65(1), 217-232.

Collier David ve Mahoney, James (1996). Insights and Pitfalls: Selection Bias in Qualitative Research. World Politics, 49 (1), 56-91.

Collier, Ruth B. ve Collier, David (1991). Shaping the political arena: Critical junctures, the labor movement, and regime dynamics in Latin America. Princeton, N.J: Princeton University Press.

Crouch, Colin (2005). Capitalist Diversity and Change. Oxford: New York: Oxford University Press

Crouch, Colin ve Streeck, Wolfgang (der) (1997). Political Economy of Modern Capitalism. London: Sage.

Dahl, Robert A. (1963). Who Governs?: Democracy and Power in the American City. New Haven: Yale University Press.

Diamond, Larry (1999). Developing Democracy: Toward Consolidation. Baltimore: Johns Hopkins University Press.

Dogan, Mattei ve Pélassy, Dominique (1990). How to Compare Nations: Strategies in Comparative Politics, Chatham, N.J: Chatham House.

Duverger, Maurice (1959). Political Parties: Their Organization and Activity in the Modern State. London: Methuen \& Co.

Duverger, Maurice (1972). Party Politics and Pressure Groups: A Comparative Introduction, New York: Thomas Y. Crowell Company.

Eckstein, Harry (1975). Case Studies and Theory in Political Science. İçinde F Greenstein ve N Polsby (der), Handbook of Political Science, vol. 7, Reading, MA: Addison-Wesley, 79-138.

Esping-Andersen, Gosta (1990). The Three Worlds of Welfare Capitalism. Princeton, N.J., Princeton University Press. 
Evans Peter (1979). Dependent Development: The Alliance of Multinational, State, and Local Capital in Brazil, Princeton, NJ: Princeton University Press.

Evans Peter vd. (1985). Bringing the State Back In, Cambridge and New York: Cambridge University Press.

Flyvbjerg, Bent (2006). Five Misunderstandings About Case-Study Research. Qualitative Inquiry, 12 (2), 219-245.

Geddes Barbara (1990). How the Cases You Choose Affect the Answers You Get: Selection Bias in Comparative Politics. Political Analysis, 2, 131-150.

George, Alexander L. ve Bennett, Andrew (2005). Case Studies and Theory Development in the Social Sciences, Cambridge, MA: MIT Press.

Gerring, John (2004). What Is a Case Study and What Is It Good for?. The American Political Science Review, 98(2), 341-354.

Gerring, John (2007). Case Study Research, New York: Cambridge University Press.

Gerring, John ve Cojocaru, Lee (2016). Selecting Cases for Intensive Analysis: A Diversity of Goals and Methods. Sociological Methods and Research, 45(3), 392-423.

Giddens, Anthony (1987). The Nation-State and Violence, California: University of California Press.

Goodin, Robert E. ve Klingemann, Hans D. (der) (1996). A New Handbook of Political Science, Oxford; New York : Oxford University Press.

Gurr, Ted (1970). Why Men Rebel, Princeton, NJ: Princeton University Press.

Hague, Rod vd. (2016). Comparative Government and Politics, London: Palgrave.

Hall, Peter A. ve Soskice, David (2001). Varieties of Capitalism: The Institutional Foundations of Comparative Advantage, Oxford: Oxford University Press.

Hall, Peter A.(1986). Governing the Economy, New York: Oxford University Press.

Hanson, Stephen ve Kopstein Jeffrey (2005). Regime Type and Diffusion in Comparative Politics Methodology. Canadian Journal of Political Science, 38(1), 69-99.

Hay, Colin (1997). Divided by a Common Language: Political Theory and the Concept of Power. Politics, 17(1), 45-52.

Heywood, Andrew (2013). Siyaset, Ankara: Adres Yayınları.

Huntington, Samuel P. (1965). Political Development and Political Decay. World Politics, 17(3), 386-430.

Huntington, Samuel P. (1968). Political Order in Changing Societies. New Haven: Yale University Press.

Huntington, Samuel P. (1996). The Clash of Civilizations and the Remaking of World Order, New York, Simon \& Schuster.

Inglehart, Ronald ve Welzel, Christian (2003). Political Culture and Democracy: Analyzing Cross-Level Linkages. Comparative Politics, 36(1), 61-79.

Kalaycıoğlu, Ersin ve Kağnıcıoğlu, Deniz (der) (2012)._Karşılaştırmalı Siyasal Sistemler, Eskişehir: Anadolu Üniversitesi Yayınları.

Katzenstein, Peter J. (1985). Small States in World Markets, Ithaca: Cornell.

Kaufman-Osborn, Timothy V. (2006). Dividing the Domain of Political Science: On the Fetishism of Subfields. Polity, 38(1), 41-71. 
Keman, Hans ve Pennings, Paul (2017). Comparative Research Methods. İçinde D. Caramani (der), Comparative Politics, Oxford: Oxford University Press, 50-65.

Kesselman, Mark (1973). Order or Movement?: The Literature of Political Development as Ideology. World Politics, 26(1), 139-154.

King, Gary vd (1994). Designing Social Inquiry: Scientific Inference in Qualitative Research, Princeton, N.J: Princeton University Press.

Kitschelt, Herbert vd (1999). Continuity and Change in Contemporary Capitalism, Cambridge: Cambridge University Press.

Klingemann, Hans D. (2008). Capacities: Political Science in Europe. West European Politics, 31 (1-2), 370-396.

Kopstein, Jeffrey ve Reilly, David A. (2000). Geographic Diffusion and the Transformation of the Postcommunist World. World Politics, 53(1), 1-37.

Laitin, David (2002) Comparative Politics: The State of the Subdiscipline. İçinde I Katznelson vd. (der), Political Science: The State of the Discipline, New York, N.Y: American Political Science Association, 630- 659.

Landman, Todd (2008). Issues and Methods in Comparative Politics, London: Routledge.

Lane, Ruth (2014). Karşılaştırmalı Siyaset Sanatı, İstanbul: Küre Yayınları.

Lapalombara, Joseph (1974). Politics Within Nations, Englewood Cliffs: Prentice-Hall.

Lasswell, Harold D. (1936). Politics: Who Gets What, When, How?, New York: McGraw-Hill.

Lasswell, Harold D. (1968). The Future of the Comparative Method. Comparative Politics 1(1), 3-18.

Lichbach, Mark I. ve Zuckerman, Alan S. (1997). Comparative Politics: Rationality, Culture, and Structure, Cambridge: Cambridge University Press.

Lijphart, Arend (1968). The Politics of Accommodation: Pluralism and Democracy in the Netherlands, Berkeley: University of California Press.

Lijphart, Arend (1971). Comparative Politics and the Comparative Method. The American Political Science Review, 65(3), 682-693.

Lijphart, Arend (1975). The Comparable-Cases Strategy in Comparative Research. Comparative Political Studies, 8 (2), 158-177.

Lijphart, Arend (1995). The Virtues of Parliamentarism: But Which Kind of Parliamentarism?. Içinde in $\mathrm{H}$ E Chehabi ve A Stepan (der), Politics, Society and Democracy. Comparative Studies, Boulder, CO: Westview Press, 363-73.

Lim, Timothy (2010). Doing Comparative Politics: An Introduction to Approaches and Issues, Boulder: Lynne Rienner.

Linz, Juan J. ve Stepan, Alfred C. (1996). Problems of democratic transition and consolidation: Southern Europe, South America, and post-communist Europe, Baltimore: Johns Hopkins University Press.

Linz, Juan J. (1990) The Perils of Presidentialism. Journal of Democracy, 1 (1), 51-69.

Linz, Juan J. (1994). Presidential or Parliamentary Democracy: Does it Make a Difference?. Içinde J Linz ve A Valenzuela (der), The Failure of Presidential Democracy, Baltimore: The Johns Hopkins University Press, 3-87.

Lipset, Martin, S. (1959). Some Social Requisites of Democracy: Economic Development and Political Legitimacy. American Political Science Review, 53, 69-105 
Mahoney, James (2004). Comparative-Historical Methodology. Annual Review of Sociology, 30, 81-101.

Mahoney, James (2007). Qualitative Methodology and Comparative Politics. Comparative Political Studies, 40(2), 122-144.

Mahoney, James ve Goertz Geary (2004). The Possibility Principle: Choosing Negative Cases in Comparative Research. The American Political Science Review, 98(4), 653-669.

Mahoney, James ve Rueschemeyer, Dietrich (der) (2003). Comparative Historical Analysis in the Social Sciences (Cambridge Studies in Comparative Politics). Cambridge: Cambridge University Press.

Mahoney, James (2000). Path Dependence in Historical Sociology. Theory and Society, 29 (4): 507-548

Mahoney, James (2001). Path Dependent Explanations of Regime Change. Studies in Comparative and International Development, 36 (1), 111-141.

Mainwaring, Scott ve Shugart Matthew S. (der) (1997). Presidentialism and Democracy in Latin America, Cambridge: Cambridge University Press.

Mayer L C (1989). Redefining Comparative Politics: Promise Versus Performance, Newbury Park, CA: Sage.

Mill, John S. (1843). A System of Logic. London: Longman.

Montesquieu (2017). Kanunların Ruhu Üzerine. Çev. Berna Günen, Ankara: Türkiye İş Bankası Kültür Yayınları.

Moore, Barrington (1967). Social Origins of Dictatorship and Democracy: Lord and Peasant in the Making of the Modern World, Boston: Beacon Press.

Morgenthau, Hans (1948). Politics Among Nations: The Struggle for Power and Peace, New York NY: Alfred A. Knopf.

Munck, Gerardo L .(2007). The Past and Present of Comparative Politics. Içinde G L Munck ve R Snyder (der). Passion, Craft, and Method in Comparative Politics: Baltimore: Johns Hopkins University Press. pp. 32-59

Neudorfer, Natascha S. (2015). Development, Democracy and Corruption: How Poverty and Lack of Political Rights Encourage Corruption. Journal of Public Policy, 35(3), 421-457.

Newton, Kenneth ve Van Deth, Jan W. (2014). Karşılaştırmalı Siyasetin Temelleri, Ankara: Phoenix Yayınevi

Nye, Joseph S. (1967). Corruption and Political Development: A Cost-Benefit Analysis. American Political Science Review, 61(2), 417-427.

O'Donnell, Guillermo A. (1973). Modernization and Bureaucratic-authoritarianism: Studies in South American Politics, Berkeley: University of California Press.

Pennings, Paul vd. (2006). Meaning and Use of the Comparative Method: Research Design. İçinde P. Pennings (vd), Doing Research in Political Science, London: SAGE, 30-52.

Pepinsky, Thomas B. (2019). The Return of the Single-Country Study. Annual Review of Political Science, 22 (1), 187-203.

Pierson, Paul (2000). Increasing Returns, Path Dependence, and the Study of Politics. American Political Science Review, 94(2), 251-267.

Pierson, Paul (2004). Politics in Time: Politics in Time: History, Institutions, and Social Analysis, Princeton University Press. 
Powell, Bingham G. vd. (2014). Comparative Politics: A Theoretical Framework, New York: Pearson Longman.

Przeworski, Adam ve Teune, Henry (1970). The Logic of Comparative Social Inquiry, New York: John Wiley \& Sons, Inc.

Przeworski, Adam vd (2000). Democracy and Development: Political Institutions and Well-Being in the World, 1950-1990, Cambridge: Cambridge University Press.

Putnam, Robert D. (1993). Making Democracy Work: Civic Traditions in Modern Italy, Princeton: Princeton University Press.

Ragin, Charles C. (1987). The Comparative Method: Moving beyond Qualitative and Quantitative Strategies, Berkeley and Los Angeles, CA: University of California Press.

Richter, Melvin (1969). Comparative Political Analysis in Montesquieu and Tocqueville. Comparative Politics, 1(2), 129-160.

Riker, William H. (1982). The Two-Party System and Duverger's Law: An Essay on the History of Political Science. The American Political Science Review, 76(4), 753-766.

Rose, Richard (1991). Comparing Forms of Comparative Analysis. Political Studies, 39: 446462.

Rostow, Walt W. (1960). The Stages of Economic Growth: A Non-Communist Manifesto. Cambridge: Cambridge University Press.

Rueschemeyer, Dietrich vd (1992). Capitalist Development and Democracy, Chicago: University of Chicago Press.

Sartori, Giovanni (1994). Compare Why and How?. İçinde M. Dogan ve A. Kazancigil (der), Comparing Nations: Concepts, Strategies, Substance, Oxford: Blackwell, 14-34.

Sartori, Giovanni (1991). Comparing and Miscomparing. Journal of Theoretical Politics, 3(3), 243-257.

Sayarı, Sabri ve Bilgin, Hasret D. (2013). Karşılaştırmalı Siyaset: Temel Konular ve Yaklaşımlar, İstanbul: Bilgi Üniversitesi Yayınları

Schumpeter, Joseph A. (1942). Capitalism, Socialism, and Democracy, New York: Harper and Brothers.

Skocpol, Theda (1979). States and Social Revolutions: A Comparative Analysis of France, Russia, and China, Cambridge: Cambridge University Press.

Skocpol, Theda (1994). Social Revolutions in the Modern World, Cambridge: Cambridge University Press.

Skocpol, Theda ve Somers, Margaret (1980). The Uses of Comparative History in Macrosocial Inquiry. Comparative Studies in Society and History, 22(2), 174-197.

Sly. Polly (2018). The Nonsense and Non-Science of Political Science: A Politically Incorrect View of "Polly-T(r)icks". Catalyst: A Social Justice Forum, 8 (1), 268-300.

Stepan, Alfred ve Skach, Cindy (1993). Constitutional Frameworks and Democratic Consolidation: Parliamentarism versus Presidentialism. World Politics 46 (1), 1-22.

Tarrow, Sidney G. (1989). Democracy and Disorder: Protest and Politics in Italy, 1965-1975, Oxford: Clarendon Press.

Tilly, Charles (1984). Big Structures, Large Processes, Huge Comparisons, Los Angeles, CA: SAGE. 
Tilly, Charles (1986). The Contentious French: Four Centuries of Popular Struggle, Cambridge, Mass.: Belknap,

Tocqueville Alexis D. (1856). The Old Regime and the Revolution, New York: Harper \& Brothers.

Tocqueville Alexis D. (1838). Democracy in America, New York :G. Dearborn \& Co.

Trent, J (2011). Should Political Science be More Relevant? An Empirical and Critical Analysis of the Discipline. European Political Science 10, 191-209.

Verba, Sidney (1967). Some Dilemmas in Comparative Research. World Politics, 20(1), 111 127.

Wallerstein, Immanuel (1974). The Modern World-System: Capitalist Agriculture and the Origins of the European World-Economy in the Sixteenth Century, New York: Academic Press.

Walton, John (1972). Political Development and Economic Development: A Regional Assessment of Contemporary Theories. Studies in Comparative International Development, 7 , 39-63.

Ward, Robert E. ve Rustow, Dankwart A. (1964). Political Modernization in Japan and Turkey, Princeton, N. J.: Princeton University Press.

Way, Lucan A. ve Levitsky, Steven (2007). Linkage, Leverage, and the Post-Communist Divide. East European Politics and Societies, 21(1), 48-66.

Wiarda, Howard (2000). Introduction to Comparative Politics: Concepts and Processes, Fort Worth: Harcourt College Publishers.

Wilson, Frank L. (1996). Concepts and Issues in Comparative Politics: An Introduction to Comparative Analysis, Upper Saddle River, N.J.: Prentice Hall.

Yayla, Atilla (2014). Karşılaştırmalı Siyasal Sistemler, Ankara: Liberte Yayınları.

Yin, Robert K. (1984). Case Study Research: Design and Methods, Thousand Oaks, CA: Sage.

Zysman, John (1983). Governments, Markets, and Growth: Financial Systems and the Politics of Industrial Change. Ithaca, NY: Cornell University Press. 